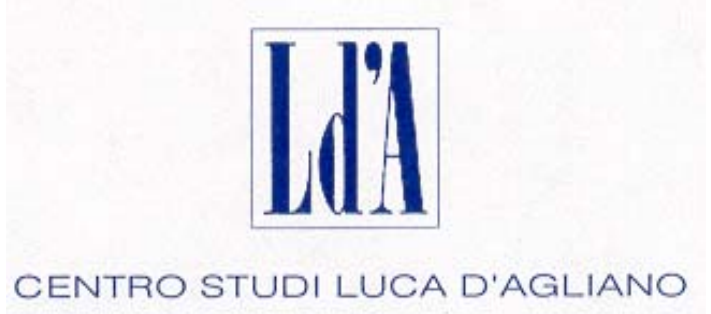

WWW.DAGLIANO.UNIMI.IT

\author{
CENTRO STUDI LUCA D'AGLIANO \\ DEVELOPMENT STUDIES WORKING PAPERS
}

N. 278

November 2009

Testing Models of Distributive Politics using Exit Polls to Measure Voters' Preferences and Partisanship

\author{
Valentino Larcinese* \\ James M. Snyder** \\ Cecilia Testa***
}

* London School of Economics and Political Science ** Massachusetts Institute of Technology

*** University of London and Centro Studi Luca d'Agliano 


\title{
Testing Models of Distributive Politics using Exit Polls to Measure Voters' Preferences and Partisanship*
}

\author{
Valentino Larcinese $\dagger$ James M. Snyder, Jr.ł and Cecilia Testa ${ }^{\S}$
}

October 6, 2009

\begin{abstract}
This paper tests various hypotheses about distributive politics by studying the distribution of federal spending across U.S. states over the period 1978-2002. We improve on previous work by using survey data to measure the share of voters in each state that are Democrats, Republicans, and independents, or liberals, conservatives and moderates. We find no evidence that the allocation of federal spending to the states is distorted by strategic manipulation to win electoral support. States with many swing voters are not advantaged compared to states with more loyal voters, nor do "battleground states" attract more federal funds. Moreover, we find that spending has little or no effect on voters' choices, whereas partisanship and ideology have massive effects.
\end{abstract}

Keywords: ideological attitudes, partisanship, distributive politics, federal budget

*We thank participants of seminars at LSE, Harvard, MIT, Columbia, Cambridge, Oxford, Ferrara, Pavia. We are grateful to James Alt, Ciro Biderman, John Patty, Albert Sole' Olle and Vera Troeger for useful comments and suggestions and to Indraneel Sircar for dedicated research assistance. The usual caveat applies. James Snyder gratefully acknowledges the financial support of National Science Foundation Grant SES-0079035.

${ }^{\dagger}$ Department of Government and STICERD, London School of Economics and Political Science.

‡Department of Political Science and Department of Economics, Massachusetts Institute of Technology.

${ }^{\S}$ Department of Economics, Royal Holloway University of London. 


\section{Introduction}

Distributive politics is a core issue in political economy, and scholars have developed a variety of models about how it works. In this paper we test three key hypotheses derived from these models, using data that has not previously been applied to this problem.

The first is the "swing voter" hypothesis, which predicts that politicians will allocate larger shares of distributive goods to groups or geographic areas that contain larger percentages of indifferent voters (who are indifferent between the political parties on ideological grounds). The second is the "electoral battleground" hypothesis, according to which distributive goods should be disproportionately allocated to districts, states, or provinces where the share of supporters of each major party is closer to $50 \%$. This hypothesis is especially relevant in systems where two major parties compete in first-past-the-post elections with geographically defined constituencies. The third is the "partisan supporters" hypothesis, which conjectures that politicians will favor areas that contain a large percentage of their core supporters. They might do this in order to send clear signals to voters, induce higher turnout, or avoid excessive deadweight costs. In all three cases, one underlying assumption is that politicians are mainly interested in winning elections and, for this purpose, they target government transfers or projects toward voters with given ideological attitudes or partisan leaning in order to attract their vote.

Testing these hypotheses is difficult. It requires measures of government spending across groups or geographic units of some sort (the dependent variable), as well as measures of the underlying partisan leanings or ideological attitudes of voters in each group or geographic unit (the key independent variables). The dependent variable is not too much of a problem, at least if one adopts the geographic approach. This is what virtually all previous empirical studies do, using the distribution of spending across units such as districts, states, or provinces. Measuring the key independent variables, however, poses a severe challenge. Researchers do not have good measures of the underlying partisan leanings or ideological attitudes of voters within each geographic unit. As a result, all but one of the previous stud- 
ies use proxy variables constructed from voting data or election outcomes. ${ }^{1}$ This is clearly problematic, however, since within models of distributive politics voting decisions are - by assumption - endogenous to the distribution of government funds. ${ }^{2}$

One important consequence of the endogeneity is that estimates of the effect of swing voters or electoral closeness on spending will often be biased toward zero. Overall, the pattern of estimates from existing studies is in fact quite mixed - some studies find statistically significant effects but many do not. However, we do not know whether the large number of insignificant coefficients reflects the fact that there is truly no relationship, or whether it is simply the result of the endogeneity bias. We demonstrate this more clearly in a simulation exercise reported below.

In this paper we use direct measures of underlying partisan leaning and voters ideological attitudes to estimate whether federal budget allocations to the states are affected by these voters' characteristics - as posited by models of distributive politics. For this purpose, we need measures that are exogenous with respect to short term policies such as the annual federal budget allocation. Dozens of political science studies over more than fifty years argue that party identification is very stable over time, and less affected by particular short-term electoral circumstances, relative to vote choice. This idea goes back at least to The American Voter (1960). Party identification is defined as a sense of personal, affective attachment to a political party based on feelings of closeness to social groups associated with the party (Campbell et al. 1960; Green at al. 2002). As Green et at. (2002) point out "identification with the political party is analogous to identification with religious, class, or ethnic group" (p 78). In other words, party identification is more of an identity than an opinion. Similarly, Goren (2005) shows that partisan identity is remarkably stable and even more stable than core political values such as principle of equal opportunity, limited government, traditional family values and moral tolerance. Moreover, he shows that past party identification has

\footnotetext{
${ }^{1}$ The one exception is Dahlberg and Johansson (2002), who use survey data to construct a measure of the percentage of swing voters in each Swedish region. Unlike us, who analyze large spending aggregates, they focus on very specific "ecological grant" program.

${ }^{2}$ Most previous studies acknowledge this problem and tend to use lagged values of the vote to mitigate the problem somewhat, but this is at best a partial solution as we will discuss later.
} 
a significant impact on current political values while the reverse is not true. Even scholars who are critical of the notion that party identification is affective, such as Fiorina (1981), argue that it is a kind of long-term moving average of past assessments of party performance. Ideology is similarly stable ${ }^{3}$. Hence, the evidence provided by the large body of studies on party identification suggests that measures based on of party identity (rather than voting decisions) can provide a valuable tool to test theories of distributive politics, because these measures are arguably much more exogenous with respect to short term policy outcomes.

To construct measures of the key independent variables used to test the alternative hypothesis derived from models of distributive politics, we use survey (exit poll) data on party identification and ideological positions. In line with the existing literature, our party identification and ideological position variables have the desirable property of being very stable and, hence, unlikely to be affected by short term policies such as the annual budget allocation we are studying. In addition, using this type of data, we can construct a direct measure of the fraction of "swing voters" in each geographic unit, since we have the fraction who call themselves "independents" (not attached to either major party) and "moderates" (not liberal or conservative). The data are for U.S. states, and the period we study is 1978-2002.

Of course, the use of survey data raises yet another potential methodological problem measurement error. Survey experts argue that measurement error varies considerably across items. Party identification appears to be relatively well measured, at least with respect to criteria such as reliability (inter-temporal stability in panels). ${ }^{4}$ Other items, such as ideology, appear much less reliable. While this may be a large problem for studies at the individual level, it is less of a problem for us since our focus is on state-level aggregates. We average over hundreds or even thousands of individuals, so even if there is a large amount of measurement error at the individual level, the measurement error in the aggregated measures should be small..$^{5}$

\footnotetext{
${ }^{3}$ See Ansolabehere, Rodden and Snyder (2006).

${ }^{4}$ See, e.g., Converse (1964) and Green et a. (2002)).

${ }^{5}$ See Page and Shapiro (1992) and Stimson (1998).
} 
Our results are easily summarized. We find little support for any of the three hypotheses listed above. We find no support for either the swing voter hypothesis or the electoral battleground hypothesis. We find mixed support for the partisan supporters hypothesis. Therefore, the allocation of federal spending to the states does not appear to be distorted by strategic manipulation to win electoral support.

The use of survey data also allows us go further than previous studies. We can also estimate the impact that government spending in a geographic area has on the vote - voting decisions now as the dependent variable and the geographic distribution of funds as an independent variable - using the survey based measures of party identification and ideology as controls. We find that spending has little or no effect on voters' choices, while partisanship and ideology have massive effects.

\section{Previous Literature}

One of the dominant theories in political economy is the so-called "swing voter" hypothesis. This posits that the allocation of distributive goods will largely go in favor of groups or regions that contain a conspicuous share of voters that are ideologically indifferent between the political parties. While voters with a clear partisan leaning rarely switch their vote to a different party, indifferent voters often do. If voters trade off their ideological stances in exchange for public funds and projects, then it is cheaper for politicians to "buy" the votes of these indifferent, or swing, voters, and competition for these voters will lead politicians to allocate disproportionate amounts of federal spending to regions or groups with many indifferent voters. Lindbeck and Weibull (1987), Dixit and Londregan (1995, 1996), and Stromberg (2004) analyze models that capture this logic.

Several studies find evidence supporting the swing voter models in some contexts, but mixed or no evidence in other contexts. Studies of the allocation of New Deal spending have found some evidence that states with a more volatile presidential vote received more federal support (Wright, 1974; Wallis, 1987, 1996; Fleck, 1999; Fishback, et al., 2003). 
However, Stromberg (2004) shows that these findings are not robust to the use of panel data methods with state fixed effects. Similarly, in a more recent study on federal budget allocation by contemporary presidents, Larcinese, et al. (2006) find that states with more frequent presidential vote swings do not receive more funds. All of these studies use lagged presidential vote returns to measure the fraction of swing voters.

The logic of distributive politics is also affected by electoral rules. In particular, winnertakes-all systems create incentives to target constituencies that are likely to be pivotal (Lizzeri and Persico, 2001; Persson and Tabellini, 2004). In other words, battleground districts may be favored both in public policy and campaign resources allocation (Snyder, 1989; Stromberg, 2005). The competitiveness of elections is particularly important in the U.S. context, where the electoral college system may induce the channeling of resources toward states that are pivotal in the presidential electoral race.

Existing empirical studies do not find a clear relationship between resource allocation and competitiveness of presidential election at state level. According to Wright (1974), U.S. states with close presidential races do not receive disproportionately more New Deal spending. Similarly, Larcinese, et al. (2006) find no evidence that states with close presidential races receive more federal monies. ${ }^{6}$. On the other hand, several studies find that battleground states receive a disproportionate share of the advertising in presidential campaigns (Colantoni, et al., 1975; Nagler and Leighley, 1990; Stromberg, 2005). All of these studies use lagged presidential vote returns to measure the two-party balance in each state.

A competing theory of distributive politics is that parties target spending toward loyal voters (Kramer, 1964; Cox and McCubbins, 1986; Dixit and Londregan, 1996; Sim, 2002; Dasgupta, et al., 2008). This can be a rational strategy in the context of low-turnout elections such as those in the U.S. If spending primarily mobilizes voters - either directly as a form of advertising or retrospective voting, or indirectly by buying the support of local elites or groups who engage in get-out-the vote efforts - then the marginal benefit to spending an

\footnotetext{
${ }^{6}$ Milligan and Smart(2003) finds that closeness of the electoral race has a positive effect on spending in the Atlantic Canadian provinces, but a negative effect in Quebec, while Crampton (2003) finds a positive correlation between competitiveness of the race and spending only in Canadian provinces which are not ruled by the liberal party
} 
additional dollar will be highest in areas with the highest density of a party's own voters. Credit-claiming issues may also provide incentives to target core areas. Who will attend the ribbon-cutting ceremonies for new bridges, schools, hospitals, and libraries? In a heavily Democratic area the politicians will almost all be Democrats, and they will leave no doubt about which party is responsible for the locality's good fortune. In electorally marginal areas, however, roughly half of the politicians will be Democrats and half will be Republicans, and the impression is not likely to be so partisan or clear. Neither party may benefit much in terms of net votes (although individual politicians, running as incumbents, may benefit).

It is also possible that spending targeted towards loyal voters could simply reflect the fact that politicians are, at least to some extent, policy oriented ${ }^{7}$. Democratic politicians may prefer spending on policies that tend to benefit Democratic voters, and likewise for Republicans. ${ }^{8}$ These alternate models are not necessarily incompatible with the swing voter hypothesis. It may be the case, for example, that the loyalists of the out-party receive disproportionately small shares of the public dollar, while swing areas and loyal areas do equally well.

Empirically, several studies find evidence that loyal voters are rewarded. Some studies find a positive relationship between the share of U.S. federal spending going to an area and the Democratic vote in the area (e.g., Browning, 1973; Ritt, 1976; Owens and Wade, 1984; Levitt and Snyder, 1995). Since Democrats were the majority party in Congress during the years studied, this provides some support for the idea that federal spoils go to the victors, but the results might also reflect the behavior of the Democratic party or the characteristics of areas that tend to vote Democratic. ${ }^{9}$ Some studies of U.S. states find a positive relationship

\footnotetext{
${ }^{7}$ See, for example, the citizen-candidates models of Osborne and Slivinski (1996) and Besley and Coate (1997).

${ }^{8}$ Besley and Case (1995) find that term limits increase the differences between the policies implemented by Republican and Democratic governors. Sole'-Olle' (2006), using Spanish data for the period 1992-99, finds that an increase in the margin of victory leads left-wing (right-wing) local governments to increase (decrease) spending, taxes and deficits.

${ }^{9}$ Levitt and Snyder (1995) compare programs passed during years of unified Democratic control with programs passed during years of divided government. They find that programs passed during unified Democratic control exhibit a pro-Democratic geographic bias, while those passed during divided government do not. Levitt and Poterba (1999) also find indirect evidence that the majority party favors its core areas: areas represented by more senior Democrats tend to get more.
} 
between spending and past share vote for the incumbent president's party (Fleck, 2003; Larcinese, et al., 2006; Garrett and Sobel, 2003). ${ }^{10}$

Finally, other theorists emphasize the importance of factors such as proposal power (Baron and Ferejohn, 1989), legislative seniority (McKelvey and Riezman, 1992), over- and under-representation (Ansolabehere et al., 2003; Knight, 2004), committee structure, presidential leadership, and universalism (Weingast et al., 1981; McCarty, 2000). If factors such as these are the main drivers of distributive spending, then there may be little relationship between spending and partisanship or ideology.

\section{Problems with measures of attitudes and partisan- ship based on voting data: a simulation}

As noted above, almost all of the existing empirical literature uses voting data to measure the percentage of swing voters, partisan balance, or the partisan disposition of each state.

One powerful critique of these measures is that voting behavior is endogenous. Most papers tend to use lagged values of the vote to mitigate the problem somewhat, but this is at best a partial solution for at least two reasons: (i) budgetary processes are sluggish, and spending in any given year depends to a large extent on decisions made in previous years, and (ii) we do not know if voters are "retrospective" or "prospective." If voters are somewhat prospective and parties keep their promises - as assumed in many models of distributive electoral politics - then lagged votes are a function of lagged promises which are equal to (or at least highly correlated with) current spending. There is a third reason to suspect that lagged vote measures are not exogenous: (iii) omitted variables that are correlated both with voting and budgetary decisions. For example, some groups might be especially favored in distributive policies because they are associated with "good values" that citizens wish to preserve (e.g., farmers), and these groups might vote in particular ways (e.g., they might

\footnotetext{
${ }^{10}$ Studies of the distribution of patronage by urban machines also find that the organizations in control of their cities tend to reward their core supporters with patronage (Holden, 1973; Rakove, 1975; Erie, 1978; Johnston, 1979).
} 
favor conservative parties).

Since the measures used by the current literature to test concurrent theories of distributive politics are clearly endogenous under a variety of assumptions, regression estimates that use them are typically biased. The sign and magnitude of the bias, however, are more difficult to determine. In the simplest cases we can compute the expected bias analytically, but most regressions that appear in the literature are fairly complicated, and typically include two or more vote-based measures in the same model. We therefore ran a series of simulated regressions. These allow us to gauge the sign and size of the bias in a set of models that are similar to many of the standard models in the literature.

The simulations show that the endogeneity of voting data can lead to severely biased estimates. More specifically, using the standard deviation of observed votes rather than the true number of independents can lead either to overestimation or underestimation of the impact of the number of independents on the allocation of federal spending, depending on the specification and the set of variables included in the regression. The effect of an electoral competition is often underestimated but sometimes also overestimated. Finally, using the observed votes to measure the partisanship of a region leads to systematic overestimation of the impact of the number of partisan voters on spending.

We consider the following basic structure. Let $j=1, \ldots, J$ index states, and let $t=1, \ldots, T$ index years. Assume all states have the same population. Let $D_{j}$ be the fraction of voters in state $j$ who are loyal to party $\mathbf{D}$, let $R_{j}$ be the fraction who are loyal to party $\mathbf{R}$, and let $I_{j}$ be the fraction who are independents (swing voters). Also, let $\tilde{D}_{j}=D_{j} /\left(D_{j}+R_{j}\right)$ be the fraction of all loyalists who are loyal to party $\mathbf{D}$, and let $\tilde{R}_{j}=R_{j} /\left(D_{j}+R_{j}\right)=1-\tilde{D}_{j}$. Let $\tilde{C}_{j}=1-\left|\tilde{D}_{j}-\tilde{R}_{j}\right|$ be the two-party "competitiveness," or partisan balance, of state $j$. Let $X_{j t}^{D}$ be the per-capita transfers that party $D$ offers to state $j$ and year $t$, and let $X_{j t}^{R}$ be the offer made by party $R$. Let $S_{j t}^{D}$ be the "electoral support" party $D$ receives in state $j$ in year $t$, and let $S_{j t}^{R}$ be the support received by party $R$. Finally, let $\tilde{V}_{j t}^{D}$ be the fraction of votes 
party $D$ receives in state $j$ in year $t$, and let $\tilde{V}_{j t}^{R}=1-\tilde{V}_{j t}^{D}$. We assume:

$$
\begin{aligned}
X_{j t}^{D} & =\alpha_{I} I_{j}+\alpha_{C} \tilde{C}_{j}+\alpha_{P} \tilde{D}_{j}+\mu_{j t}^{D} \\
X_{j t}^{R} & =\alpha_{I} I_{j}+\alpha_{C} \tilde{C}_{j}+\alpha_{P} \tilde{R}_{j}+\mu_{j t}^{R} \\
S_{j t}^{D} & =\beta_{I} X_{j t}^{D} I_{j}+\left(1+\beta_{P} X_{j t}^{D}\right) D_{j}+\epsilon_{j t}^{D} \\
S_{j t}^{R} & =\beta_{I} X_{j t}^{R} I_{j}+\left(1+\beta_{P} X_{j t}^{R}\right) R_{j}+\epsilon_{j t}^{R} \\
\tilde{V}_{j t}^{D} & =S_{j t}^{D} /\left(S_{j t}^{D}+S_{j t}^{R}\right)
\end{aligned}
$$

If $\alpha_{I}>0, \beta_{I}>0$ and $\alpha_{C}=\alpha_{P}=\beta_{P}=0$ then we have a linearized approximation of the "swing voter" model of Lindbeck and Weibull (1987) and Dixit and Londregan (1995, 1996). If $\alpha_{P}>0, \beta_{P}>0, \alpha_{I} \geq 0, \beta_{I} \geq 0$, and $\alpha_{C}=0$ then we have something like the "machine politics" model of Dixit and Londregran (1996) or the model of Cox and McCubbins (1986), or what Fishbeck, et al. (2003) call the mandate model. Finally, if $\alpha_{C}>0, \alpha_{I} \geq 0, \beta_{I} \geq 0$, $\beta_{P} \geq 0$, and $\alpha_{P}=0$, then we have something approximating the model of Milligan and Smart (2005), or the electoral college model of Colantoni, et al., (1975), Stromberg (2002) and others. ${ }^{11}$

If researchers had direct measures of $I_{j}, D_{j}$ and $R_{j}$, then they could construct $\tilde{C}_{j}, \tilde{D}_{j}$ and $\tilde{R}_{j}$, and then directly estimate equations (1) and (2). In almost all cases, however, they do not. Instead, they use measures based on the actual vote shares, $\tilde{V}^{D}$. Beginning with Wright (1974), researchers have often used the standard deviation of $\tilde{V}^{D}$ over a set of elections within each state $j$ as a proxy for $I_{j}$. Intuitively, if $I_{j}$ is large then $\tilde{V}^{D}$ will vary widely across elections in state $j$, and the standard deviation of $\tilde{V}^{D}$ in state $j$ will be large. ${ }^{12}$ Researchers also tend to use some historical average of $\tilde{V}^{D}$ as a proxy for $\tilde{D}_{j}$, and an analogous average as a proxy for $\tilde{R}_{j}$. Finally, researchers usually use some historical average of $-\left|\tilde{V}^{D}-\tilde{V}^{R}\right|$ as a proxy for $\tilde{C}_{j}$.

As noted above, there are many reasons why even historical voting measures are not

\footnotetext{
${ }^{11}$ This formulation does not do justice to some of these models, such as Stromberg (2002), which takes into account the total probability a state is "pivotal" in the electoral college.

${ }^{12}$ Trending partisanship could also produce a large standard deviation of $\tilde{V}^{D}$, which is a potential problem.
} 
exogenous: (i) budgetary lags; (ii) voters could be "prospective" and (iii) there are probably omitted variables that are correlated both with voting patterns and budgetary decisions. Rather than constructing complicated historical averages and autocorrelation structures that attempt to incorporate these features more precisely, we simply use contemporaneous voting data freely in our simulated regressions. Let $\bar{V}_{j}^{D}=(1 / T) \sum_{t=1}^{T} \tilde{V}_{j t}^{D}$ be the mean of $V^{D}$ in state $j$ over a sample of $T$ years, and let $\hat{I}_{j}=\left[(1 / T) \sum_{t=1}^{T}\left(\tilde{V}_{j t}^{D}-\bar{V}_{j}^{D}\right)^{2}\right]^{1 / 2}$ be the sample standard deviation. Also, let $\hat{C}_{j t}=1-\left|\tilde{V}_{j t}^{D}-\tilde{V}_{j t}^{R}\right|$ be the closeness of the election in state $j$ in year $t$.

We consider the following specifications:

$$
\begin{aligned}
\text { Model 1a } & : \quad X_{j t}^{D}=a_{I} \hat{I}_{j}+\mu_{j t} \\
\text { Model 1b } & : \quad X_{j t}^{D}=a_{C} \hat{C}_{j t}+\mu_{j t} \\
\text { Model 1c } & : \quad X_{j t}^{D}=a_{P} \tilde{V}_{j t}^{D}+\mu_{j t} \\
\text { Model 2a } & : \quad X_{j t}^{D}=a_{I} \hat{I}_{j}+a_{C} \hat{C}_{j t}+\mu_{j t} \\
\text { Model 2b } & : \quad X_{j t}^{D}=a_{I} \hat{I}_{j}+a_{P} \tilde{V}_{j t}^{D}+\mu_{j t} \\
\text { Model 2c } & : \quad X_{j t}^{D}=a_{C} \hat{C}_{j t}+a_{P} \tilde{V}_{j t}^{D}+\mu_{j t} \\
\text { Model 3 } & : \quad X_{j t}^{D}=a_{I} \hat{I}_{j}+a_{C} \hat{C}_{j t}+a_{P} \tilde{V}_{j t}^{D}+\mu_{j t} \\
\text { Model } 4 & : \quad X_{j t}^{D}=a_{I} I_{j}+a_{C} \hat{C}_{j t}+a_{P} \tilde{V}_{j t}^{D}+\mu_{j t}
\end{aligned}
$$

We only analyze party $\mathbf{D}$, since analogous specifications for party $\mathbf{R}$ would simply duplicate the results. Note that in Model 4 we use the actual value of $I_{j}$ rather than the vote-based measure. This approximates the "encompassing models" in Dahlberg and Johansson (2002), which include a survey-based measure of $I$, but vote-based measure of $V_{D}$.

In each simulation, we set $J=50$ and $T=100$, i.e. 50 states over 100 years. Note that this gives much more data on the time dimension than researchers actually have. We do this to focus attention more on the bias produced by endogeneity than on measurement error bias (which also plagues the literature). In all cases, $I, D$, and $R$, are drawn from independent uniform distributions on $[0,1]$. Also, in each simulation, $I, D$, and $R$ are fixed for all 100 
years (i.e., all $t=1, \ldots, 100)$. Next, we choose values for the parameters $\alpha_{I}, \alpha_{C}, \alpha_{P}, \beta_{I}$, and $\beta_{C}$. Finally, we draw $\mu^{D}, \mu^{R}, \epsilon^{D}$ and $\epsilon^{R}$ from independent uniform distributions. We set the standard deviations of $\mu^{D}$ and $\mu^{R}$ to $\sigma_{\mu}$, and the standard deviations of $\epsilon^{D}$ and $\epsilon^{R}$ to $\sigma_{\epsilon}$.

We focus on four different cases. In Case 1 and Case 2 there is no partisan targeting, that is, $\alpha_{P}=0$. In addition, we assume there is no partisan voter response to transfers, that is, $\beta_{P}=0$. The difference between the two cases is the value of $\sigma_{\mu}$, the degree to which the distribution of transfers across states is determined by random, idiosyncratic factors. In Case $1, \sigma_{\mu}=.2$, so the idiosyncratic factors are relatively important. In Case $2, \sigma_{\mu}=.03$, so the idiosyncratic factors are less important. In Case 3 and Case 4 there is partisan targeting, with $\alpha_{P}=.5$. We also assume there is a partisan voter response, with $\beta_{P}=.5$. The difference between the two cases is again the value of $\sigma_{\mu}$, with $\sigma_{\mu}=.2$ in Case 3 and $\sigma_{\mu}=.03$ in Case 4 . Inside each case, we vary the parameters $\alpha_{I}$ and $\alpha_{C}$. We fix $\beta_{I}=1$ and $\sigma_{\epsilon}=.09$ throughout the simulations.

For each vector of parameters we run 10,000 simulated regressions. Table 1 presents the averages of the estimates of the parameters of interest ${ }^{13}$. To give an example, if we take model $2 \mathrm{a}$, the first row gives the average estimates of, respectively, $\alpha_{I}(.01)$ and $\alpha_{C}(.08)$ when the true values of these parameters are both set equal to 0 : the columns on the left of Table 1 report the true values in each case. We observe a number of patterns.

First, in most cases the average estimates of $a_{P}$ are biased upward. That is, there is a strong tendency to find "partisan targeting" predicted by the mandate model or machine politics model, even when it does not exist. The effect is large when idiosyncratic factors have a large impact on transfers. This is a direct result of the assumption that independent voters respond to transfers in their voting behavior. When one party happens to spend more than the other party in a state - whether due to the exogenous factors captured in $\mu^{D}$ and $\mu^{R}$, or to actual partisan targeting - then many independent voters will vote for that party, producing a spurious additional correlation between transfers and votes.

Second, the average estimates of $a_{I}$ tend to be biased downward, but are sometimes

\footnotetext{
${ }^{13}$ Rather than reporting all possible specifications, we focus on $\widehat{\alpha}_{I}$ and $\widehat{\alpha}_{C}$ in cases 1 and 2 , and on $\widehat{\alpha}_{P}$ in cases 3 and 4 . However, we always report the results for the case where all variables are included.
} 
biased upward. They can even have the wrong sign: this appears to be especially the case when $\sigma_{\mu}$ is low and $a_{I}$ is high. The average estimates of $a_{I}$ are not even monotonic in the true value of $\alpha_{I}$, as we can see in the models $2 \mathrm{~b}$ and 3 of case 3 .

Also, the average estimates of $a_{I}$ are often biased even when the true $I_{j}$ are used (model 4): this is because the other vote-based measures are endogenous and may be correlated with $I_{j}$. In fact, the bias on $a_{I}$ can be even larger using the true $I_{j}$ : this is especially the case when the true $I_{j}$ is low.

Third, the average estimates of $a_{C}$ are sometimes biased downward and sometimes biased upward. When $\sigma_{\mu}$ is low the coefficient is generally underestimated, while if $\sigma_{\mu}$ is high then the coefficient can be biased both upwards and downwards depending on the specification.

The difficulty in recovering the true parameters is well illustrated if we consider model 3 , which is similar to many specifications used in the empirical literature. Here when $\sigma_{\mu}$ is high (cases 1 and 3 ) the estimate of $\alpha_{P}$ is systematically and substantially upward biased. If instead $\sigma_{\mu}$ is low (cases 2 and 4 ), then we obtain a much more precise estimate of $\alpha_{P}$. This comes at the cost, however, of a deterioration in the estimates of $\alpha_{I}$. In fact, there appears to be a trade-off between the consistency of $\widehat{\alpha}_{P}$ and the consistency of $\widehat{\alpha}_{I}$. The intuition is straightforward. As noted above, a large degree of random variation in the allocation of spending induces more support to be directed at parties simply by voters' reaction to the spending. Many independents therefore act as if they are partisans, generating a spurious positive correlation between observed votes and observed spending. At the same time, however, a more random allocation of funds facilitates the identification of the electoral response to spending. Since independent voters respond to spending, random variation in the allocation of funds will produce large fluctuations in their voting behavior. The standard deviation of the vote is then a relatively good measure of the proportion of independent voters. In fact, this means that we encounter a type of contradiction: the swing voter hypothesis is testable (using voting data) only insofar as it is false, i.e. only insofar as funds are randomly allocated rather than targeted to independent voters. 


\section{The data}

We analyze U.S. federal budget allocation to the states during the period from 1978 to 2002 to test the various hypothesis about distributive politics. We consider three dependent variables: (1) total federal spending per-capita, (2) total spending other than direct transfers to individuals, per-capita, and (3) federal grants per-capita. The second variable should allow us to isolate the most manipulable items in the budget, since it removes the largest of the "non-discretionary" or "entitlement" programs, such as Social Security, Medicare, pensions for public officials, AFDC (TANF), etc. ${ }^{14}$ The third variable is arguably the most targetable; and while it is much smaller than (1) or (2) it still constitutes an important part of state finances. In all cases, our dependent variables are outlays.

It is important to consider that there is a lag between the appropriation and the spending of federal funds. This is relevant when estimating the effect of particular institutional and political variables, since current federal outlays have normally been appropriated in previous calendar years. For this reason, we will always consider lagged values of the political explanatory variables.

As noted above, one of the main independent variables of interest is the percentage of swing voters in a state. We use poll data to measure the share of "independents" (and also the share of Democratics and Republicans). These data are from exit polls conducted by various news organizations - CBS News, CBS News/New York Times, ABC News, ABC News/Washington Post, and Voter News Service. ${ }^{15}$ Voters are interviewed briefly after leaving the polling booth, and asked how they voted. They are also asked to provide their party identification (Democrat, Republican, other, or independent), and their ideological leaning (liberal, conservative, moderate, or don't know). ${ }^{16}$ Importantly, these questions are designed to tap into voters' general self-identification, rather than how the voters have just

\footnotetext{
${ }^{14}$ Interest on the debt is not included in either dependent variable.

${ }^{15}$ Voter News Service is an association of ABC News, CNN, CBS News, FOX News, NBC News and the Associated Press.

${ }^{16}$ In addition, voters are asked a series of questions about their demographic and socio-economic characteristics, questions about the reasons for their vote choice, and, sometimes, questions about salient policy issues.
} 
voted. Two typical forms of the party identification question are: "Regardless of how you voted today, do you normally think of yourself as a [Democrat], [Republican], [Independent], [Something Else]?"; and "Do you normally think of yourself as a [Democrat], [Republican], [Independent]?" Two common forms of the ideology question are: "On most political matters, do you consider yourself [liberal], [moderate], [conservative]?"; and "Regardless of the party you may favor, do you lean more toward the liberal side or the conservative side politically [liberal], [conservative], [somewhere in between]?"

Using this information we can construct state-level variables reporting the percentage of voters that declare themselves Democratic, Republican or Independent. Due to the relatively small number of interviewed in some states in some years, we aggregate the results over four-year periods (two elections). We assess the reliability of these variables with respect to exogeneity and measurement error problems in section 4.1 below.

\subsection{Endogeneity and measurement error in survey data}

One concern is how well survey data can capture the distribution of partisanship within states. This issue is discussed extensively in Erikson, Wright and McIver (1993), who conclude that the partisanship measures derived from the surveys correlate in the expected way with observable other criteria like other polls, election returns and party registration. A number of checks induce us to think that these data capture the underlying distribution of partisanship by state quite well and that they are preferable to using simple voting results. Figure 1 plots the share of Democratic vote by state (averaged across all years) on the share of Democratic partisans in the survey data. Figure 2 does the same for Republicans. There is clear positive correlation between votes and partisanship, especially for the Republican party. Although our purpose is to go beyond what can be captured by voting data, the correlation between the exit poll measures and observed votes is reassuring and suggests that our measure can be taken as a reliable indicator of partisanship. Of course, actual votes also include non-partisans and final election results are crucially affected by the leaning, in a particular election, of independent voters. Hence, figure 3 reports the aggregate Democratic 
share of votes at presidential elections and the share of Democratic supporters from exit polls: it clearly shows that partisanship is much more stable of what electoral results would suggest and that using voting to measure partisanship can therefore be problematic. ${ }^{17}$ In figure 4 we report the standard deviation (over the period we consider) of presidential Democratic votes by state and compare with the standard deviation of party identification: again, this figure suggests that partisanship is much less volatile than voting. Hence, our survey data confirm the stable pattern of party identity variables found by other studies supporting the notion of party identity as a long term stable personal characteristic as opposed to the variable pattern of voting data. ${ }^{18}$

\subsection{Testing distributive politics hypotheses using survey data}

One key prediction of the swing voter hypothesis is that states that have more Independents should receive more federal funds. The alternative theories of distributive politics conjecture that the competitiveness of elections and the share of loyal voters may also affect the distribution of federal funds to the states. Thus, we will test these predictions by using measures of the share of independents, of electoral closeness and of loyal voters that, differently from previous work, are not based on actual voting data but on survey data. Indicating with Dem, Rep, and Ind, respectively the share of Democrats, Republicans and Independents, we use Ind to measure the share of independents and $(1-|D e m-R e p|)$ to measure closeness.

We tried other measures of partisan and independent voters as well. Some voters may be "cross-pressured," in the sense that they identify themselves with a party that is not the closest on the ideological dimension. This is the case for liberal Republicans (not uncommon in the northeast) and conservative Democrats (still common in the south and west). Such voters are probably more prone to defect in any given election. Thus, we considered an alternative measure of independent voters, in which cross-pressured voters are included with the self-identified independents. In this specification, partisan Democratic voters will there-

\footnotetext{
${ }^{17}$ This is consistent with Green, Palmquist and Schickler (2002).

${ }^{18}$ This is consistent with the findings of Green et al. (2002) and Goren (2005).
} 
fore only be either liberal or moderate, while Republicans will only be either conservative or moderate. The substantive conclusions do not change when we use these variables, so we do not report the results ${ }^{19}$.

As discussed in the introduction, swing voter models predict that states with higher partisan and/or ideological balance should receive less funds, while the opposite is predicted by models that stress the importance of loyal voters. If legislators reward their supporters, we should observe that incumbents divert money toward states with high shares of voters ideologically leaning toward the incumbent legislator. In the U.S. institutional setting the incumbent is never a unitary actor since federal budget allocation involves both Congress and the president. Therefore, we construct different measures of partisanship by interacting the party affiliation of various actors with the shares of voters that declare to have the same party affiliation of the actor under consideration. To evaluate whether the president favors his supporters we use the variable Presidential Copartisans, which is equal to the share of Democratic voters when the incumbent president is a Democrat and the share of Republican voters when the president is Republican. ${ }^{20}$

In addition to political considerations, a variety of demographic factors might directly affect federal spending. Thus, in all regressions we include per-capita income, percent elderly, percent in schooling age and total state population. ${ }^{21}$ Moreover, it is clear that the two states bordering the District of Columbia - Maryland and Virginia - receive more funds simply because of the spill over of federal government activities. A similar case can be made for New Mexico because of the long term investments in military spending. Thus, in the cross section regressions we always include dummy variables for these three states.

\footnotetext{
${ }^{19}$ Results are available from the authors upon request.

${ }^{20} \mathrm{We}$ constructed analogous variables using the party affiliation of the majority in the house (House Majority Copartisans) and senate (Senate Majority Copartisans) as well as the political affiliation of state senators (Senator Copartisans). The results are substantively the same as those obtained in the case of president affiliation. We do not report them here but they are available from the authors upon request.

${ }^{21}$ The total population size captures the effects of malapportionment of the U.S. Senate, as small states are extremely over-represented. It may, however, also capture budgetary lags. Because of "incremental budgeting," the growth of the population is likely to negatively affect the levels of expenditure per capita. If there are lags in adjusting the allocation of transfers to population shifts, then, as a state population grows its per-capita transfers will automatically fall. Economies of scale might also lead to a negative effect of population on per-capita transfers.
} 
The sources for all variables used in our analysis are reported in Table 4.

\section{Results}

The simulation exercise shows that regressions based on voting data can be substantially biased. By using more exogenous measures based on exit polls, we should be able to obtain less biased estimates. It is therefore important to compare the results in the two cases to verify whether we obtain different estimates. We can then use the simulation exercise as a benchmark to evaluate the potential bias in estimated coefficients.

The key test of the swing voter model is whether the coefficients on the share of independents is positive. We compare, therefore, the results obtained when the share of independents from the exit polls is used as explanatory variable with the results obtained when observed votes are used. In this case we use the standard deviation of Democratic vote in the previous three presidential elections. The "battleground state" hypothesis stresses the role of the state marginality: thus, we also estimate regressions with closeness as explanatory variable for spending. Results when the competitiveness of electoral races is measured using exit polls can then be compared with regressions when closeness is measured by using voting data. Finally, we test the alternative possibility that loyal voters get more funds. Again, we compare results when the share of votes for the incumbent president is used as explanatory variable with results when exit polls partisan measures are used instead.

To check the robustness of our results we consider several possible variants of these basic models. We first consider specifications in which swing, pivotality and partisan measures are all included in the same regression. Since swing, pivotality, and partisanship are somewhat correlated, and since the various hypotheses regarding these variables are not logically incompatible with each other, specifications that include only one variable at a time might suffer from omitted variable bias. We also consider the possibility that the share of swing voters and the closeness could have a positive interaction. Unfortunately the two variables

are highly correlated and there appears to be little to learn from such exercise. The results 
always display insignificant coefficients for the interaction term and are not reported. There is also the possibility that open primaries induce more people to define themselves independent. We identify Massachusetts and Rhode Island as two states where this is a serious possibility. Therefore all regressions have been repeated by excluding those two states. We noticed very limited variations in the results (not reported) ${ }^{22}$.

Using yearly data when voting data are not available for each year (and the closest past election is therefore imputed to subsequent years) can generate autocorrelation in the residuals with the potential problems this generates for standard errors estimates. Hence, in addition to using state-level clustered standard errors, we also run term-based regressions, in which each presidential term is collapsed into one observation and the spending and other control variables are averaged over the period.

Finally, we study three alternative dependent variables. In one specification we use targetable spending, i.e. we remove from total federal expenditure the least manipulable categories such as entitlements. In another specification we use federal grants rather than total spending. Grants contain a larger share of discretionary spending and also often provide the state government with some discretion over the way money is spent. Thus, receiving more grants should be favorably regarded both by the citizens and by the administrators of a given state.

Since we consider a large number of specifications, we only report the coefficients of our variables of interest in the main text. ${ }^{23}$ These are reported in Table 2 . We should point out that for the standard control variables, we do not find any significant surprises or noticeable differences across the various specifications. The percentage of aged has a positive and significant effect on total federal outlays, while the percentage of school-age children has a negative significant impact. The coefficient of population (in logarithm) is negative and significant in most specifications, while the coefficient of income per capita is negative and significant only when fixed effects are introduced.

\footnotetext{
${ }^{22}$ Results are available from the authors upon request.

${ }^{23}$ Detailed results are shown in the appendix.
} 


\subsection{Share of swing voters}

The key test of the swing voter hypothesis consists in verifying whether the relationship between the share of independents and spending is positive. We begin with a simple scatterplot of the collapsed data, averaged over the period 1978-2002. This is shown in figure 5. In each of the four graphs, the y-axis is average federal spending other than direct transfers. The $\mathrm{x}$-axis measures the share of swing voters, and we do this four different ways. In figure $5(\mathrm{a})$, we use the average share of voters who identify themselves as moderates; in 5(b) we use the share who identify themselves as independents, in 5(c) we use the share who identify themselves both as moderate and independent, and in 5(d) we use the share who identify themselves both as moderate and independent or who are cross-pressured (voters who are liberal and Republican or conservative and Democratic). Each graph also shows a line of the predicted values from a bivariate regression of spending on the corresponding $\mathrm{x}$-variable. Evidently, the relationships are all pretty weak - none of the estimated slope coefficients are significant even at the 20 percent level. We can do a bit better by dropping the three states which are outliers in terms of average spending - Maryland, New Mexico, and Virginia - or by including a dummy variable for these states. In this case the relationship between federal spending and the share of swing voters becomes statistically significant at the 10 percent level for the measure used in figure 5(c), but not for the other three measures.

Table 2 presents the main results. There we report estimates of the main coefficient of interest from model 1 (with exit poll measures) and model 2 (with voting measures), and model 7 (with other political variables from exit polls are also introduced) and model 8 (where other political variables from voting data are introduced). We find no evidence that states with a larger share of independent voters receive more funds. This result is robust across various specifications, i.e. whether we use yearly or term data, whether we include or not state fixed effects and whether we use federal expenditure, targetable spending or grants as our dependent variable.

The situation is slightly different when we use the standard deviation of past vote. In this case, the coefficient is insignificant in cross section regressions but it becomes negative 
and significant in regressions with total federal spending (and, in one case, with targetable spending) when state fixed effects are included. This is the opposite of what the swing voter model would predict: a higher share of swing voters (measured by the standard deviation of Democratic vote) induces less spending. However, this is also consistent with our simulations, where we found that the coefficient of the share of independent voters tend to be biased downward when voting data are used and can even assume a negative sign while the true parameter is positive. This result is particularly evident when we compare model 7 and 8 , i.e. when we also consider closeness and partisan alignment within the same specification. A negative sign for $\beta$ in model 8 (when voting data are used) is much more common (and significant, in some cases) than a negative sign for $\beta$ in model 7 (when exit poll data are used).

Hence, we do not find support for the basic prediction of the swing voter model. ${ }^{24}$ States with more independent voters do not receive more federal funds. Also, while based on the regressions with voting data one might be tempted to conclude that states with more independents may actually be penalized, we can in fact conclude, also on the basis of our simulation exercise, that the negative sign is most likely due to endogeneity problems.

\subsection{Battleground states}

We conduct a similar investigation focusing on the "competitiveness" of the electoral race for presidential elections. This time the results using poll data (model 3) and voting data (model 4) are quite similar. The coefficient for a close race is negative, i.e. states with closer races receive less funds. This runs against the predictions of models based on the swing voter logic. This result, however, only holds in cross section analysis and is not robust to the introduction of state fixed effects in the case of total and targetable spending, although in

\footnotetext{
${ }^{24}$ Dahlberg and Johansson (2002), using survey data, find support for the swing voter hypothesis in the allocation of "ecological grants" to swedish municipalities. Although in comparing their results with ours some caveats apply as their standard errors do not appear to have been clustered by constituency and the Swedish Election Study is also not guaranteed to be representative at a constituency level, yet their different results suggest that tactical distribution may be working in their case because of the different institutional setting and very specific discretionary spending program they analyze.
} 
this last case the coefficients are not significant. The situation is reversed when we consider grants: now the negative sign prevails when state fixed effects are introduced but vanishes in cross section analysis. The magnitude of the negative effect of closeness is larger when we use poll data measures (with the exception of grants regressions). There is one important difference between the voting and the exit poll regressions: in the first case, the results are not robust to the introduction of other political variables (model 8), while the results in model 7 (poll data) are surprisingly similar to those of model 3. A prevalence of the negative sign remains when we remove the cross-pressured voters from the bulk of the partisans (not reported).

The main conclusion that we derive is that, when significant, the coefficient displays a sign which is opposite to what the "battleground states" hypothesis would predict. Using voting data delivers a very incoherent set of results, and this again conforms to the variability that we found in the simulation exercise. However, using the poll data does not seem to make any substantial difference in this case, although the results appear more robust to specification variations, at least in term of the significance of the coefficients.

\subsection{Partisan supporters}

An alternative to the swing voter hypothesis is that politicians reward loyal voters. We consider this possibility from the presidential point of view since this is most common in the literature. Thus, we first consider the share of vote for the incumbent president's party as the relevant measure of state partisanship and use it as an explanatory variable of spending. On the other side, from the exit polls we know the share of voters who identify themselves with each party and can therefore use this variable to measure partisanship. These alternative measures are considered in models 5 and 6 . Looking at Table 2 , it is clear that this is the only hypothesis that even receives partial support from the data. It is also clear, however, that using voting data to measure partisanship (model 6) leads to a significant overestimation of this effect. This is consistent with the findings of our simulation exercise. In model 6 , the partisan share coefficient is always positive and, in some cases, significant at the $5 \%$ 
level. In model 5 the only significant coefficients are again positive; this time, however, some negative coefficients occur and the magnitude of the effect is generally (although not always) smaller. Introducing other political variables (model 7 and 8) induces some changes in magnitudes and significance levels. In this case the polling data measure of partisanship is always positive and, in four cases, significant at the $10 \%$ level. Detracting cross-pressured voters from the count of the partisans do not alter in any significant way these results. We conclude that this is the only hypothesis for which we find significant coefficients with the correct sign and never a significant coefficient with the wrong sign, just the opposite of what we found in the previous cases.

\section{Effects of government expenditures on voting}

Our previous results cast some doubt on the idea that voters are responsive to the receipt of federal funds. In fact, one of the premises of the swing voter model is that politicians can buy votes by favoring certain groups in terms of spending allocation: swing voters are then simply cheaper to buy, given their lack of unconditional attachment to a given party. Hence, in this section we turn to the other side of the coin, and ask whether voters do in fact respond to favorable spending by rewarding incumbent politicians. By using exit poll data we estimate the impact of federal spending on individual voting decisions, controlling for partisanship and ideological leaning. Including such controls means that, to a large extent, we mitigate possible endogeneity problems for the spending variable.

We analyze voting decisions in presidential, gubernatorial, senate and house elections. In the first three cases, the swing voter model would posit that incumbents are rewarded for the receipts of federal funds and therefore the dependent variable is a dummy equal to 1 if the voter chooses the incumbent (or a candidate from the incumbent's party). In the case

of the House we cannot predict how funds (which are measured at the state level) should affect voting for particular incumbents, given that within a state there are simultaneously many House representatives, usually from both parties. Moreover, we only know the state of 
each voter, not her district. Thus, in this case the dependent variable is a dummy equal to 1 if a vote is cast for a Democratic candidate, and the explanatory variable of interest is an interaction term between the amounts received and the share of Democratic representatives from the state. ${ }^{25}$

Table 2 reports our estimations when total federal expenditure in the state is used as explanatory variable. It is clear that the fact that a state receives more federal funds does not induce its citizens to cast more votes in favor of incumbents. The coefficient of total federal expenditure can be even negative and never reaches a $5 \%$ significance level, in spite of the very large number of observations. On the contrary, partisanship and ideology have massive effects. These results are consistent with Bartels (2005) who finds evidence of a strong impact of partisanship on voting behavior both at presidential and congressional level.

When we use targetable spending, our results do not show substantial variations, with the exception of a positive coefficient on the probability of voting for an incumbent governor. Even in this case, however, the significance level (10\%) appears rather weak for a sample of this size. For presidential election we encounter again a negative coefficient although only significant at the $10 \%$ level. Grants are totally insignificant in the president, governor and senator equations. They appear instead to have a positive impact in the probability of voting for a Democrat in Congress when the majority of state representatives in Congress is Democrat. This is the only coefficient we encounter which turns out to be significant at the $5 \%$ level. Although this could be the consequence of the specification we use (not being able to identify the district of the voters), this is also consistent with related findings by Stein and Bickers (1994) and Levitt and Snyder (1995). ${ }^{26}$

\footnotetext{
${ }^{25}$ Before moving into the regression analysis we have checked how well self-reported individual data could predict actual state-level electoral results. This is a potential problem for any survey-based analysis of voting decisions. We find a correlation coefficient of 0.792 between the results predicted by the exit poll data and actual electoral results.

${ }^{26}$ The estimates reported in Table 3 assume that all voters should be affected in the same way by the receipt of federal funds. This is not necessarily the case. Hence, we have considered specifications that introduce interactions between the spending variables and the partisanship and ideological variables. The results suggest that heterogeneous responses are sometimes possible but that, overall, these effects are hardly statistically significant, particularly considering the size of the sample. Detailed results are reported in the appendix.
} 
Overall, the evidence that receiving more federal funds induces voters to reward incumbent politicians is rather weak. ${ }^{27}$ One possible objection to this conclusion is that, according to swing voter models, in equilibrium, both candidates converge on the same platform: hence, in equilibrium, we should expect no effect, but this does not imply that voters would not react to spending proposals. The idea that electoral competition brings platform convergence appears, in reality, to run against historical evidence. The two major American parties have often proposed very different platforms on spending as well as on other matters. ${ }^{28}$ Although identifying causal relationships is not straightforward, there appears to be a clear correlation between the platform proposals and the implemented policies, which is consistent with the "mandate" model (Budge and Hofferbert, 1990; King and Laver 1993). At the district level the situation does not appear much different: individual candidates for the House have also been shown to systematically assume divergent positions (Erikson and Wright, 1997; Ansolabehere, et al., 2001). Another possible explanation for our findings is that although parties (or candidates) do not converge, our estimates nonetheless capture equilibrium behavior that masks structural coefficients. Suppose, for example, that candidates typically manage to meet voters' expectations, or fulfill their campaign promises, regarding spending. Then we may find little correlation in the data because we do not observe "out-of-equilibrium" behavior. Thus, while our findings are consistent with the hypothesis that voters rarely respond with their votes to public spending in a clear and systematic way, further research is clearly needed to rule out other possibilities.

\section{Conclusion}

Our findings regarding the allocation of federal spending across U.S. states are disappointing for theories of distributive politics, but are good news for the working of institutions, designed

\footnotetext{
${ }^{27}$ Some other studies in the literature also find insignificant effects of state expenditure on voting, e.g. Besley (2006).

${ }^{28}$ See, for example, Sundquist (1983). The different stances on the role of public spending to stimulate the economy taken by the Democrats and the Republicans during the great depression constitute a prime example of policy platform divergence on spending issues, and one that has had long lasting consequences on the subsequent evolution of the two parties.
} 
to provide checks and balances, preventing legislators from abusing their power by tailoring budget allocations to their political goals. We find no support for the notion that parties target areas with high numbers of swing voters. We also find no support for the notion that parties target battleground states. We find limited and mixed support for the notion that parties target areas with high numbers of their partisan supporters. Since we find no significant effect of distributive spending on voting decisions, it seems most likely that to the extent that partisan targeting occurs, it is driven more by the policy-motivations of politicians than by strategic calculations to win electoral support.

Our findings might reflect features of distributive politics that are particular to the U.S.. Congress, one of the most powerful and decentralized national legislatures in the world. It jealously guards its control over the public purse. Committees are powerful, and jealously guard their own jurisdictions. Strong norms of seniority rule give committee leaders and members a substantial degree of independence from party leaders. Individual senators and representatives frequently pursue their own re-election goals, working to "bring home the bacon" for their state or district. The federal structure of the U.S., with strong and autonomous state governments, further complicates the situation. For example, many federal grants to states are either matching or project grants, and decisions by state governments therefore affect where federal money flows. As a result, the president may have relatively little influence over the geographic distribution of federal expenditures. Perhaps, even though he would like to target swing states or swing voters, he cannot. Further investigations in other institutional settings are necessary to establish the validity of this conclusion. 


\section{REFERENCES}

Ansolabehere, Stephen, Jonathan Rodden and James M. Snyder., Jr. 2006. Issue Preferences and Measurement Error, mimeo, MIT.

Ansolabehere, Stephen, James M. Snyder, Jr., and Charles Stewart, III. 2001. "Candidate Positioning in U.S. House Elections." American Journal of Political Science 45: 136159.

Ansolabehere, Stephen, James M. Snyder, Jr., and Michael M. Ting. 2003. "Bargaining in Bicameral Legislatures: When and Why Does Malapportionment Matter?" American Political Science Review 97: 471-481.

Atlas, Cary M., Thomas W. Gilligan, Robert J. Hendershott, and Mark A. Zupan. 1995. "Slicing the Federal Net Spending Pie: Who Wins, Who Loses, and Why." American Economic Review 85: 624-629.

Baron, David P., and John Ferejohn. 1989. "Bargaining in Legislatures." American Political Science Review 83: 1181-1206.

Bartels, Larry M. 2000. "Partisanship and Voting Behavior, 1952-1996." American Journal of Political Science 44: 35-50.

Besley, Timothy. 2006. Principled Agents? The Political Economy of Good Government.. Oxford University Press.

Besley, Timothy and Anne Case. 1995. "Does electoral accountability affect economic policy choices? Evidence from gubernatorial term limits". Quarterly Journal of Economics 110(3): 769-798.

Besley, Timothy and Steven Coate. 1997. "An economic model of representative democracy." Quarterly Journal of Economics 108: 85-114.

Browning, Clyde E. 1973. "The Geography of Federal Outlays." Studies in Geography No. 4. Chapel Hill: University of North Carolina Department of Geography.

Budge, Ian, and Richard I. Hofferbert. 1990. "Mandates and Policy Outputs: U.S. Party Platforms and Federal Expenditures." American Political Science Review 84: 111-131.

Case, Anne. 2001. "Election Goals and Income Redistribution: Recent Evidence from Albania." European Economic Review 45: 405-423.

Colantoni, Claude S., Terrence J. Levesque, and Peter C. Ordeshook. 1975. "Campaign Resource Allocation Under the Electoral College." American Political Science Review 69: 41-161.

Cox, Gary W. and Matthew D. McCubbins, 1986. "Electoral politics as a Redistributive Game." Journal of Politics 48: 370-389.

Crampton, Eric. 2004. "Distributive Politics in a Strong Party System: Evidence from Canadian Job Grant Programs." Discussion Paper, University of Canterbury.

Dahlberg, Matz, and Eva Johansson. 2002. "On the Vote Purchasing Behavior of Incumbent Governments." American Political Science Review 96: 27-40.

Dasgupta, Sugato, Amrita Dhillon, and Bhaskar Dutta. 2008. "Electoral Goals and CentreState Transfers: A Theoretical Model and Empirical Evidence from India." Journal of Development Economics, forthcoming.

Dixit, Avinash, and John Londregan. 1995. "Redistributive Politics and Economic Efficiency." American Political Science Review 89: 856-866. 
Dixit, Avinash, and John Londregan. 1996. "The Determinants of Success of Special Interests in Redistributive Politics." Journal of Politics 58: 1132-1155.

Erie, Stephen P. 1978. "Politics, the Public Sector, and Irish Social Mobility: San Francisco, 1870-1900." Western Political Quarterly 31: 274-289.

Erikson, Robert S., Gerald C. Wright, and John P. McIver. 1989. "Political Parties, Public Opinion, and State Policy in the United States." American Political Science Review 83: 729-749.

Erikson, Robert S., Gerald C. Wright, and John P. McIver. 1993. Statehouse Democracy: Public Opinion and Policy in the American States. Cambridge: Cambridge University Press.

Erikson, Robert S. and Gerald C. Wright. 1997. "Voters, Candidates, and Issues in Congressional Elections." In Congress Reconsidered, 6th edition, edited by Lawrence C. Dodd and Bruce I. Oppenheimer. Washington: Congressional Quarterly Press.

Fiorina, Morris P. 1981. Retrospective Voting in American Elections. New Haven: Yale University Press.

Fishback, Price V., Shawn Kantor, and John J. Wallis. 2003. "Can the New Deal Three-R's be Rehabilitated? A County-by-County, Program-by-Program Analysis." Explorations in Economic History 40 (July): 278-307.

Fleck, Robert K. 1999. "Electoral Incentives, Public Policy, and the New Deal Realignment." Southern Economic Journal 65: 377-404.

Garrett, Thomas A., and Russel S. Sobel. 2003. "The Political Economy of FEMA Disaster Payments," Economic Inquiry 46(3 July): 496-509.

Green, Donald, Bradley Palmquist, and Eric Schickler. 2002. Partisan Hearts and Minds. Political Parties and the Social Identities of Voters. New Haven, CT: Yale University Press.

Goren, Paul. 2005. "Party Identification and Core Political Values." American Journal of Political Science 49:881-896.

Holden, Matthew. 1973. White Man's Burden. New York: Chandler.

Horiuchi, Yusaku, and Jun Saito. 2001. "Electoral Reform and the Distribution of Public Expenditures: Evidence from Japan." Unpublished manuscript, National University of Singapore.

ICPSR. 1995. General Election Data for the United States, 1950-1990 [Computer file]. ICPSR ed. Ann Arbor, MI: Inter-university Consortium for Political and Social Research [producer and distributor].

Johnston, Michael. 1979. "Patrons and Clients, Jobs and Machines: A Case Study of the Uses of Patronage." American Political Science Review 73: 385-398.

King, Gary and Michael Laver. 1993. "On Party Platforms, Mandates, and Government Spending." American Political Science Review, 87 (September): 744-750.

Knight, Brian G. 2006. "Estimating the Value of Proposal Power". American Economic Review, forthcoming.

Kramer, Gerald H. "A Decision-Theoretic Analysis of a Problem in Political Campaigning." In Mathematical Applications in Political Science, volume 11, edited by Joseph L. Bernd. Dallas, TX: Southern Methodist University. 
Larcinese, Valentino, Leonzio Rizzo, and Cecilia Testa. 2006. "Allocating the US Federal Budget to the States: the Impact of the President." Journal of Politics, 68 (May): 447-456.

Levitt, Steven D., and James M. Poterba. 1999. "Congressional Distributive Politics and State Economic Performance." Public Choice 99: 185-216.

Levitt, Stephen D., and James M. Snyder, Jr. 1995. "Political Parties and the Distribution of Federal Outlays." American Journal of Political Science 39: 958-980.

Lindbeck, Assar, and Jorgen W. Weibull. 1987. "Balanced-Budget Redistribution as the Outcome of Political Competition." Public Choice 52: 273-297.

Lizzeri, Alessandro and Nicola Persico. 2001. "The Provision of Public Goods under Alternative Electoral Incentives." American Economic Review. 91: 225-239.

McCarty, Nolan M. 2000. "Presidential Pork: Executive Veto Power and Distributive Politics." American Political Science Review 94: 117-129.

McKelvey, Richard D., and Raymond Riezman. 1992. "Seniority in Legislatures." American Political Science Review 86: 951-965.

Milligan, Kevin, and Michael Smart 2003. "Regionalism and pork barrel politics." Unpublished manuscript, University of Toronto.

Milligan, Kevin, and Michael Smart. 2005. "Regional Grants as Pork Barrel Politics." Unpublished manuscript, University of Toronto.

Nagler, Jonathan, and Jan Leighley. 1992. "Presidential Campaign Expenditures: Evidence on Allocations and Effects." Public Choice. 73(3)-April.310-333.

Osborne, M.J. and A. Slivinski 1996. "A model of political competition with citizencandidates" Quarterly Journal of Economics. 111, 65-96.

Owens, John R., and Larry L. Wade. 1984. "Federal Spending in Congressional Districts." Western Political Quarterly 37: 404-423.

Page, Benjamin I., and Robert Y. Shapiro. 1992. The Rational Public: Fifty Years of Trends in Americans' Policy Preferences. Chicago: University of Chicago Press.

Persson, Torsten and, Guido Tabellini. 2004. "Constitutional Rules and Fiscal Policy Outcomes." American Economic Review 94: 25-46.

Rakove, Milton. 1975. Don't Make No Waves, Don't Back No Losers. Bloomington, IN: Indiana University Press.

Ritt, Leonard G. 1976. "Committee Position, Seniority, and the Distribution of Government Expenditures." Public Policy 24: 469-497.

Sim, Feng-ji. 2002. "Mobilizing the Masses: Party Strategy with Political Mobilization." Unpublished SM Thesis, Massachusetts Institute of Technology.

Snyder, James M., Jr. 1989. "Election Goals and the Allocation of Campaign Resources," Econometrica 57: 637-660.

Sole'-Olle', Albert. 2006. "The Effects of Party Competition on Budget Outcomes: Empirical Evidence from Local Governments in Spain", Public Choice 26: 145-176.

Stein, Robert M., and and Kenneth N. Bickers. 1994. "Congressional Elections and the Pork Barrel." Journal of Politics. 56: 377-399 . 
Stimson, James A. 1998. Public Opinion in America: Moods, Cycles, and Swings. Boulder CO: Westview Press.

Stromberg, David. 2004. "Radio's Impact on Public Spending." Quarterly Journal of Economics 119 (February): 189-221.

Stromberg, David. 2005. "How the Electoral College Influences Campaigns and Policy: The Probability of Being Florida." Working Paper, Institute for International Economic Studies, Stockholm University.

Sundquist, James L. 1983. Dynamics of the Party System: Alignment and Realignment of Political Parties in the United States. Washington, DC: The Brookings Institute.

Wallis, John J. 1987. "Employment, Politics and Economic Recovery during the Great Depression." Review of Economics and Statistics 69: 516-20.

Wallis, John J. 1996. "What Determines the Allocation of National Government Grants to the States?" NBER Historical Paper No. 90.

Weingast, Barry R., Kenneth A. Shepsle and Christopher Johnsen. 1981. "The Political Economy of Benefits and Costs: A Neoclassical Approach to Distributive Politics." Journal of Political Economy 89: 642-664.

Wright, Gavin. 1974. "The Political Economy of New Deal Spending: An Econometric Analysis." Review of Economics and Statistics. 56: 30-38. 
Table 1: Simulation Results

Case 1: $\alpha_{P}=\beta_{P}=0, \beta_{I}=1.0, \sigma_{\mu}=.7, \sigma_{\epsilon}=.3$

\begin{tabular}{|c|c|c|c|c|c|c|c|c|c|c|c|}
\hline & & Model 1a & Model 1b & Mo & el $2 a$ & & odel & & & del & \\
\hline$\alpha_{I}$ & $\alpha_{C}$ & $\hat{a}_{I}$ & $\hat{a}_{C}$ & $\hat{a}_{I}$ & $\hat{a}_{C}$ & $\hat{a}_{I}$ & $\hat{a}_{C}$ & $\hat{a}_{P}$ & $\hat{a}_{I}$ & $\hat{a}_{C}$ & $\hat{a}_{P}$ \\
\hline 0.0 & 0.0 & -.00 & .09. & .01 & .09 & .01 & .09 & .28 & -.00 & .09 & .28 \\
\hline 0.0 & 0.5 & - & .40 & .06 & .41 & .05 & .40 & .24 & . 11 & .39 & .24 \\
\hline 0.0 & 1.0 & - & .55 & .09 & .58 & .07 & .57 & .20 & .26 & .56 & .20 \\
\hline 0.5 & 0.0 & .42 & - & .43 & .18 & .43 & .18 & .30 & .49 & .08 & .30 \\
\hline 0.5 & 0.5 & - & - & .40 & .61 & .40 & .60 & .27 & .54 & .44 & .27 \\
\hline 0.5 & 1.0 & - & - & .32 & .87 & .31 & .86 & .23 & .63 & .71 & .23 \\
\hline 1.0 & 0.0 & .49 & - & .56 & .44 & .57 & .43 & .31 & .99 & .07 & .31 \\
\hline 1.0 & 0.5 & - & - & .53 & .90 & .53 & .89 & .29 & 1.00 & .48 & .28 \\
\hline 1.0 & 1.0 & - & - & .41 & 1.17 & .40 & 1.15 & .25 & 1.05 & .81 & .24 \\
\hline
\end{tabular}

Case 2: $\alpha_{P}=\beta_{P}=0, \beta_{I}=1.0, \sigma_{\mu}=.1, \sigma_{\epsilon}=.3$

\begin{tabular}{|c|c|c|c|c|c|c|c|c|c|c|c|}
\hline & & Model 1a & Model 1b & Mode & $2 \mathrm{a}$ & & odel & & & odel & \\
\hline$\alpha_{I}$ & $\alpha_{C}$ & $\hat{a}_{I}$ & $\hat{a}_{C}$ & $\hat{a}_{I}$ & $\hat{a}_{C}$ & $\hat{a}_{I}$ & $\hat{a}_{C}$ & $\hat{a}_{P}$ & $\hat{a}_{I}$ & $\hat{a}_{C}$ & $\hat{a}_{P}$ \\
\hline 0.0 & 0.0 & .00 & .00 & .00 & .00 & .00 & .00 & .01 & .00 & .00 & .01 \\
\hline 0.0 & 0.5 & - & .27 & .07 & .30 & .07 & .29 & .00 & .15 & .28 & .00 \\
\hline 0.0 & 1.0 & - & .24 & .11 & .27 & .09 & .28 & .00 & .32 & .28 & .00 \\
\hline 0.5 & 0.0 & .15 & - & .21 & .15 & .21 & .14 & .01 & .50 & .00 & .00 \\
\hline 0.5 & 0.5 & - & - & .24 & .52 & .23 & .51 & .00 & .57 & .36 & .00 \\
\hline 0.5 & 1.0 & - & - & .23 & .70 & .22 & .69 & .00 & .69 & .58 & .00 \\
\hline 1.0 & 0.0 & -.61 & - & $-.64_{3}$ & $1^{-.08}$ & -.64 & -.08 & .00 & 1.00 & .00 & .01 \\
\hline 1.0 & 0.5 & - & - & -.53 & .25 & -.54 & .24 & .01 & 1.01 & .41 & .00 \\
\hline 1.0 & 1.0 & - & - & -.34 & .61 & -.37 & .58 & .02 & 1.08 & .70 & .01 \\
\hline
\end{tabular}


Table 1: Simulation Results (continued)

Case 3: $\alpha_{P}=\beta_{P}=.5, \beta_{I}=1.0, \sigma_{\mu}=.7, \sigma_{\epsilon}=.3$

\begin{tabular}{|ll|cc|cc|ccc|ccc|}
\hline & & \multirow{2}{*}{ Model 2b } & Model 2c & \multicolumn{3}{|c|}{ Model 3 } & \multicolumn{2}{|c|}{ Model 4} \\
\hline$\alpha_{I}$ & $\alpha_{C}$ & $\hat{a}_{I}$ & $\hat{a}_{P}$ & $\hat{a}_{C}$ & $\hat{a}_{P}$ & $\hat{a}_{I}$ & $\hat{a}_{C}$ & $\hat{a}_{P}$ & $\hat{a}_{I}$ & $\hat{a}_{C}$ & $\hat{a}_{P}$ \\
\hline 0.0 & 0.0 & -.00 & .84 & .05 & .84 & -.00 & .06 & .85 & .00 & .06 & .85 \\
0.0 & 0.5 & - & - & .38 & .78 & .10 & .40 & .78 & .13 & .38 & .78 \\
0.0 & 1.0 & - & - & .60 & .70 & .13 & .65 & .70 & .28 & .62 & .70 \\
0.5 & 0.0 & .39 & .89 & - & - & .39 & .04 & .90 & .50 & .05 & .90 \\
0.5 & 0.5 & - & - & - & - & .43 & .56 & .85 & .58 & .41 & .85 \\
0.5 & 1.0 & - & - & - & - & .36 & .89 & .78 & .69 & .71 & .78 \\
1.0 & 0.0 & .28 & .92 & - & - & .27 & .12 & .93 & 1.00 & .04 & .93 \\
1.0 & 0.5 & - & - & - & - & .29 & .65 & .89 & 1.05 & .45 & .89 \\
1.0 & 1.0 & - & - & - & - & .12 & .92 & .84 & 1.12 & .78 & .84 \\
\hline
\end{tabular}

Case 4: $\alpha_{P}=\beta_{P}=.5, \beta_{I}=1.0, \sigma_{\mu}=.1, \sigma_{\epsilon}=.3$

\begin{tabular}{|c|c|c|c|c|c|c|c|c|c|c|c|}
\hline \multirow[b]{2}{*}{$\alpha_{I}$} & \multirow[b]{2}{*}{$\alpha_{C}$} & \multicolumn{2}{|c|}{ Model 2b } & \multicolumn{2}{|c|}{ Model 2c } & \multicolumn{3}{|c|}{ Model 3} & \multicolumn{3}{|c|}{ Model 4} \\
\hline & & $\hat{a}_{I}$ & $\hat{a}_{P}$ & $\hat{a}_{C}$ & $\hat{a}_{P}$ & $\hat{a}_{I}$ & $\hat{a}_{C}$ & $\hat{a}_{P}$ & $\hat{a}_{I}$ & $\hat{a}_{C}$ & $\hat{a}_{P}$ \\
\hline 0.0 & 0.0 & -.00 & .60 & .00 & .60 & .00 & .00 & .60 & -.00 & .00 & .60 \\
\hline 0.0 & 0.5 & - & - & .30 & .54 & .07 & .32 & .54 & . 17 & .31 & .54 \\
\hline 0.0 & 1.0 & - & - & .43 & .45 & .02 & .44 & .45 & .38 & .47 & .45 \\
\hline 0.5 & 0.0 & -.14 & .66 & - & - & -.19 & -.08 & .66 & .50 & .00 & .66 \\
\hline 0.5 & 0.5 & - & - & - & - & -.36 & .12 & .61 & .60 & .37 & .61 \\
\hline 0.5 & 1.0 & - & - & - & - & -.68 & .19 & .55 & .75 & .61 & .54 \\
\hline 1.0 & 0.0 & -.81 & .70 & - & - & $32^{-.89}$ & -.21 & .70 & 1.00 & .00 & .70 \\
\hline 1.0 & 0.5 & - & - & - & - & -1.17 & -.20 & .66 & 1.07 & .40 & .66 \\
\hline 1.0 & 1.0 & - & - & - & - & -1.59 & -.23 & .60 & 1.17 & .71 & .61 \\
\hline
\end{tabular}




\section{Variables: Definition and Sources}

- Exit Poll data. We use questions on reported vote, party identification and ideology. Party identification question are typically of the form: "Regardless of how you voted today, do you normally think of yourself as a [Democrat], [Republican], [Independent], [Something Else]?"; ideology questions are typically of the form: "regardless of the party you may favor, do you lean more toward the liberal side or the conservative side politically [liberal], [conservative], [somewhere in between]?". The share of Democratic (Republican, Independent) is then constructed by aggregating individual observations by state. We have proceeded analogously for the ideology data. This information is available every two years but aggregated over four year periods to avoid small samples in some states. Only samples of at least 100 hundred observations have been used. Very few cases have been deleted using this method. All regressions have been repeated not excluding these cases and they deliver the same results. Once obtained the 4-years aggregates, data have been smoothed assuming that variations in ideology and partisanship are gradual (and keeping fixed the years of presidential elections). For example, $D_{1985}=0.25 D_{1984}+0.75 D_{1988} ; D_{1986}=0.5 D_{1984}+0.5 D_{1988}$; $D_{1987}=0.25 D_{1984}+0.75 D_{1988}$. The data obtained with this procedure have been finally lagged by one period. The share of swing voters is measured by the share of independents. Closeness is measured as $1-|D-R|$. Partisanship fo the incumbent president is. $D$ when the president is democratic and $R$ when the president is republican. Sources: CBS News, New York Times, ABC News, Washington Post, Voters News Service.

- Spending data. Federal Expenditure, Targetable Expenditure (defined as Federal Expenditure-Direct Payments to Individuals), Grants are all in real and per capita terms. Targetable spending is total federal expenditure minus direct payments to individuals. Source: Statistical Abstract of the United States.

- Voting Data. Defining as $\widetilde{D}$ the share of Democratic vote in the last election and $\widetilde{R}$ the share of Republican vote in the last election, we always consider $D=\widetilde{D} /(\widetilde{D}+\widetilde{R})$ and $R=1-D$. Swingness is measured as the standard deviation of $D$ in the previous three presidential elections. Election closeness is defined as $1-|D-R|$. The share of vote for the incumbent president is $D$ when the president is democratic and $R$ when the president is republican. Source: Statistical Abstract of the United States.

- Socioeconomic data. Real Income per capita, Population (in logarithms), Percentage Elderly (above 65), and Percentage in Schooling Age (5-17), are taken from the Statistical Abstract of the United States. 
Fig. 1: Democratic vote share and partisanship by state

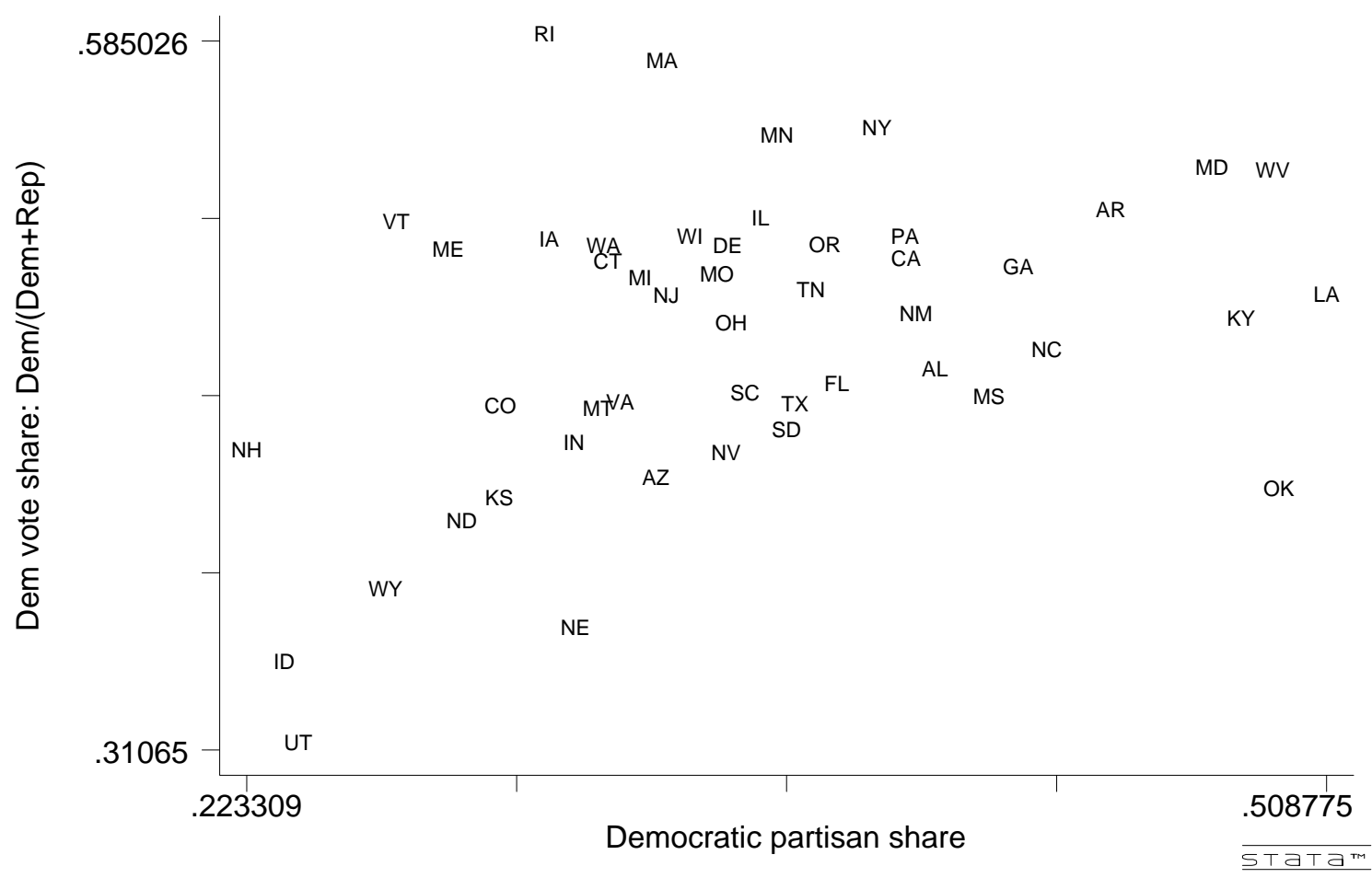


Fig. 2: Republican vote share and partisanship by state

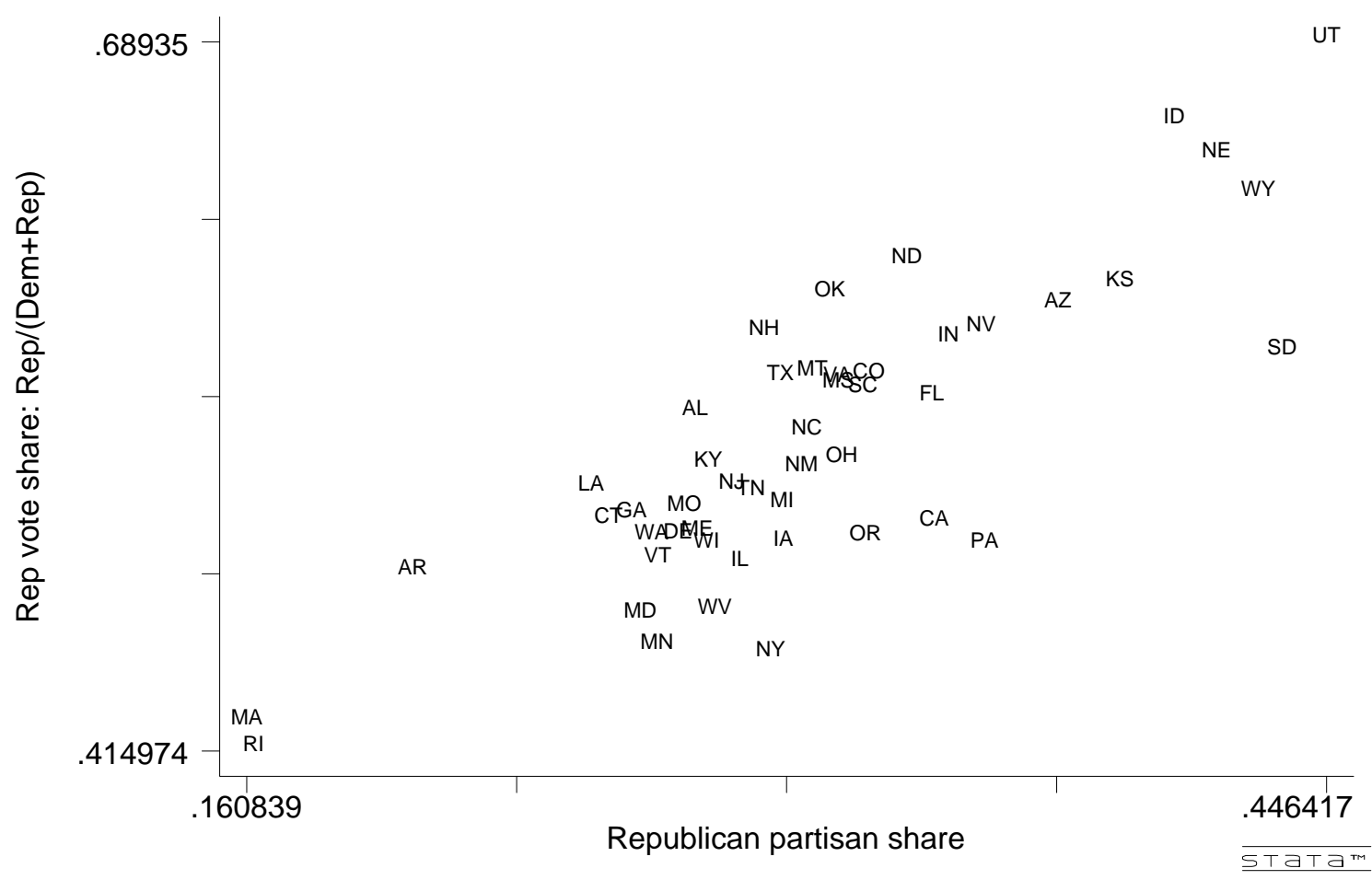




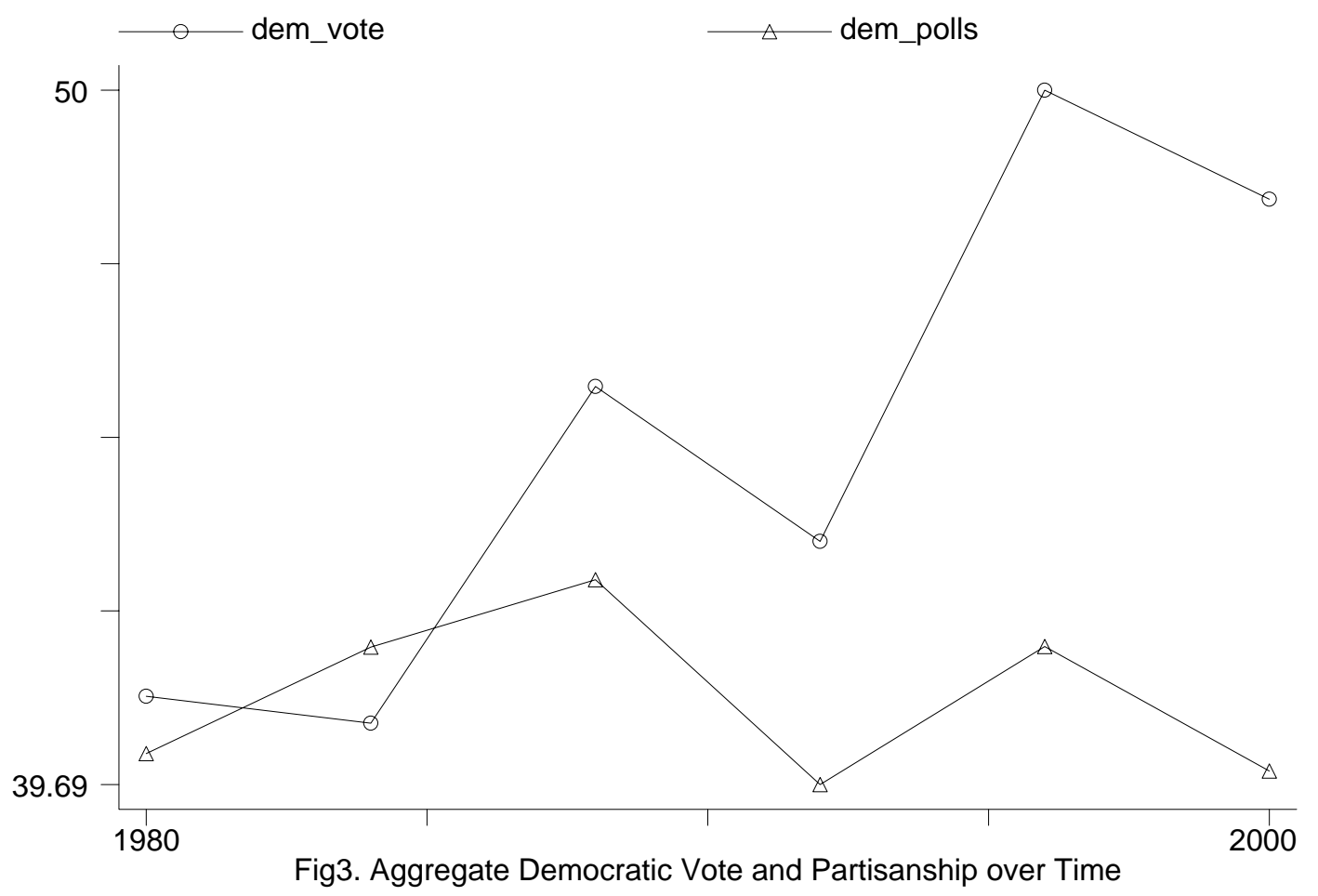

Fig3. Aggregate Democratic Vote and Partisanship over Time 


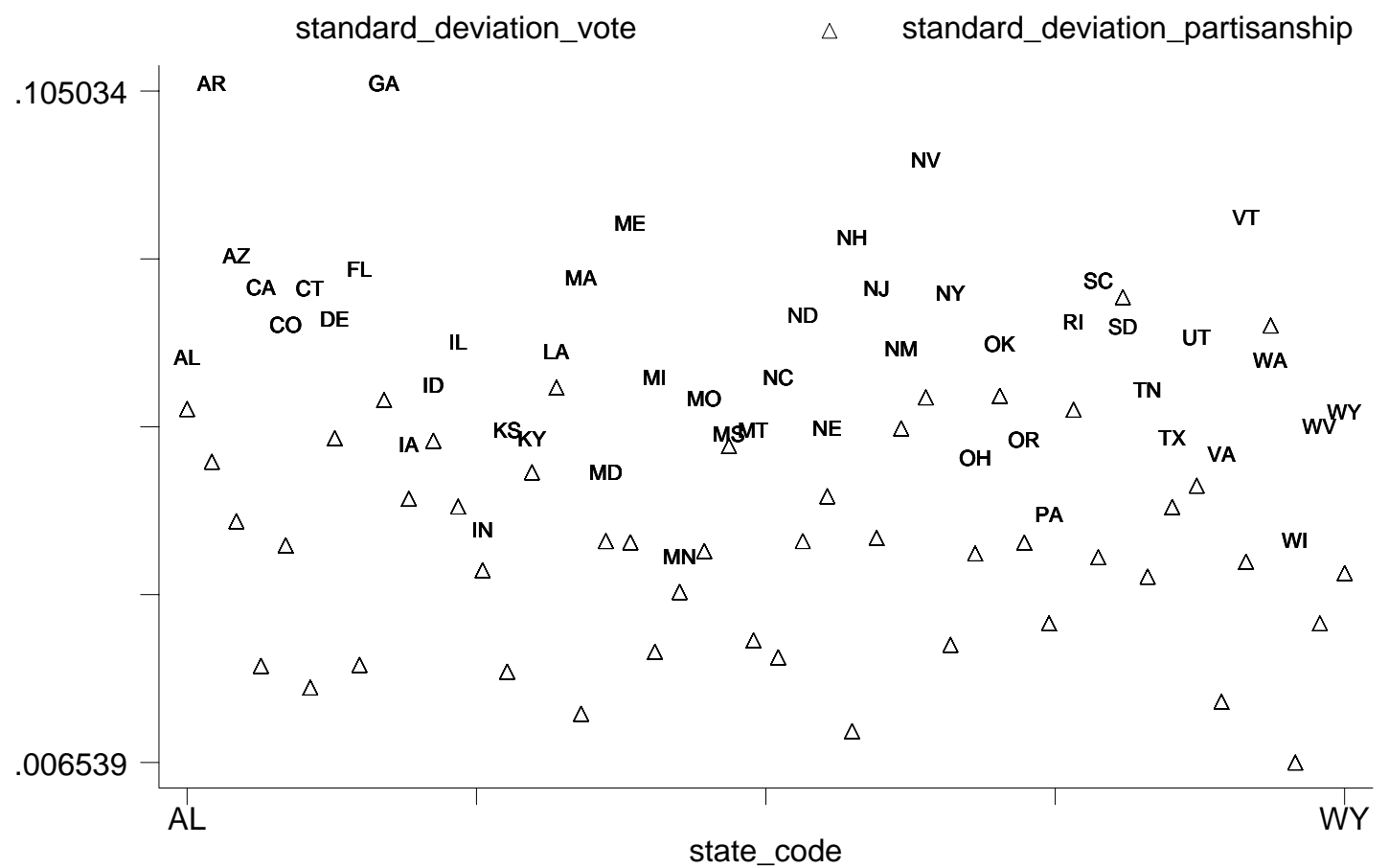

Fig.4: Standard dev. of Democratic vote and partisanship by State 

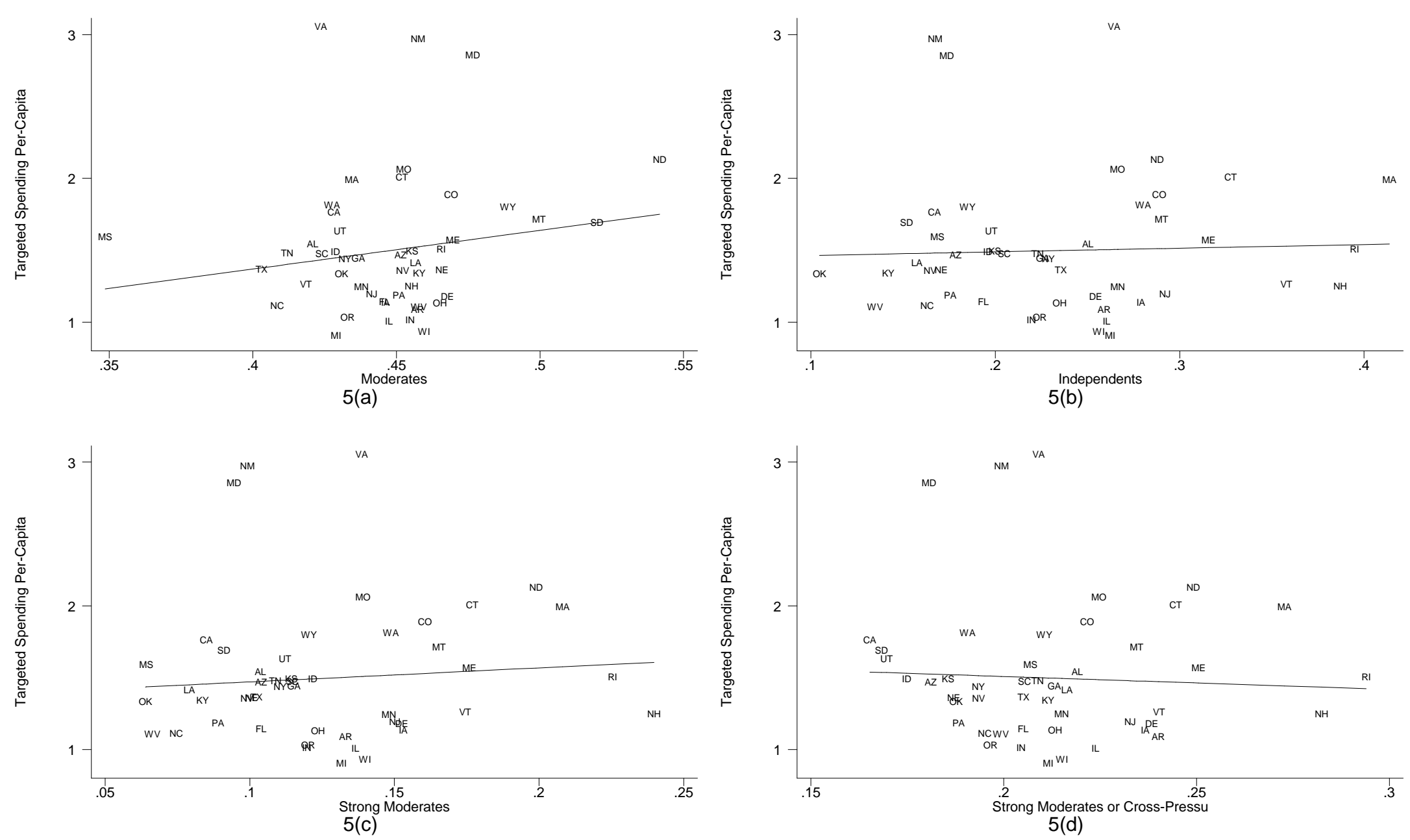

Figure 5 
Model

Coefficients

Dep. Variable Time Unit State F.E.

fed. exp.

fed. exp.

fed. exp.

fed. exp.

targetable

targetable

targetable

targetable

grants

grants

grants

grants

Model

Coefficients

Dep Variable

fed. exp.

fed. exp.

fed. exp.

fed. exp.

targetable

targetable

targetable

targetable

grants

grants

grants

grants year no

term no

term yes

year no

year yes

term no

term yes

year no

year yes

term no

term yes year yes model 1 model 2 model 3 model 4 model 5 model 6

\begin{tabular}{|c|c|c|c|c|c|}
\hline$\beta$ & $\beta$ & $\gamma$ & $\gamma$ & $\delta$ & $\delta$ \\
\hline & & & & & \\
& & & & & \\
0.34 & 0.54 & $-0.86^{*}$ & $-0.49^{*}$ & -0.09 & $0.46^{*}$ \\
-0.35 & $-1.3^{* *}$ & 0.19 & 0.1 & $0.37^{* *}$ & 0.11 \\
0.24 & 0.73 & -0.85 & $-0.7^{* *}$ & -0.02 & $0.83^{* *}$ \\
0.15 & $-1.29^{* *}$ & 0.2 & -0.01 & $0.41^{* *}$ & $0.33^{*}$ \\
0.42 & 0.27 & -0.68 & -0.35 & -0.26 & 0.16 \\
-0.38 & -0.88 & 0.11 & 0.06 & 0.2 & -0.03 \\
0.28 & 0.44 & -0.63 & $-0.54^{*}$ & -0.11 & $0.56^{* *}$ \\
-0.31 & -0.93 & 0.2 & 0.00 & 0.18 & 0.08 \\
0.11 & -0.11 & -0.16 & -0.01 & -0.04 & 0.05 \\
0.08 & 0.01 & 0.03 & $-0.09^{*}$ & 0.06 & $0.1^{* *}$ \\
0.13 & 0.05 & -0.17 & -0.09 & -0.05 & 0.09 \\
0.22 & 0.1 & -0.00 & $-0.13^{* *}$ & 0.05 & $0.11^{* *}$ \\
\hline
\end{tabular}

model $7 \quad$ model 8

\begin{tabular}{|c|cc|c|cc|}
\hline$\beta$ & $\gamma$ & $\delta$ & $\beta$ & $\gamma$ & $\delta$ \\
\hline & & & & & \\
& & & & & \\
0.45 & $-0.86^{*}$ & 0.19 & 0.38 & -0.52 & -0.11 \\
-0.10 & 0.18 & $0.35^{*}$ & $-1.46^{\star *}$ & 0.37 & $0.58^{\star *}$ \\
0.40 & -0.85 & 0.25 & 0.28 & -0.59 & 0.26 \\
0.39 & 0.22 & $0.46^{\star *}$ & $-1.40^{\star *}$ & 0.17 & $0.57^{\star *}$ \\
0.42 & -0.68 & 0.01 & 0.27 & -0.63 & -0.44 \\
-0.26 & 0.1 & 0.16 & 0.92 & 0.21 & 0.17 \\
0.33 & -0.63 & 0.08 & 0.1 & -0.51 & 0.08 \\
-0.21 & 0.21 & 0.17 & -0.99 & 0.00 & 0.15 \\
0.13 & -0.16 & 0.03 & -0.14 & -0.00 & 0.05 \\
0.14 & 0.04 & 0.08 & -0.04 & -0.07 & 0.03 \\
0.15 & -0.17 & 0.03 & -0.01 & -0.08 & 0.02 \\
0.26 & 0.00 & 0.07 & 0.01 & -0.12 & 0.01 \\
\hline
\end{tabular}

Each cell corresponds to a regression, of which only the relevant coefficient is reported. Detailed results can be found in the Statistical Appendix. Indicating with I the share of independents, with $\sigma$ the standard deviation of Democratic vote, with CP and CV the closeness between the two main parties measured, respectively, using poll and voting data and with PP and PV the share of partisan supporters for the incumbent president measured, respectively, with poll and voting data, the more general models are specified as follows:

model 7: $X_{s t}=\alpha+\eta_{s}+\lambda_{t}+\beta l_{s t}+\gamma C P_{s t}+\delta P P_{s t}+\theta Z_{s t}+e_{s t}$

model 8: $X_{s t}=\alpha+\eta_{s}+\lambda_{t}+\beta \sigma_{s t}+\gamma C V_{s t}+\delta P V_{s t}+\theta Z_{s t}+e_{s t}$

where $\mathrm{X}$ is expenditure (federal expenditure, targetable spending or grants), $Z$ are control variables (real income per capita, share of population aged 5-17, share of elderly, total population), s stands for state and $t$ for the time unit (year or presidential term). Model 1 and model 2 set $\gamma=\delta=0$ and use, respectively, $I$ and $\sigma$. Models 3 and 4 set $\beta=\delta=0$ and use, respectively, CP and CV. Models 5 and 6 set $\beta=\gamma=0$ and use, respectively, PP and PV. All regressions are repeated both with and without ns (as indicated).

When fixed effects are not used we introduce control dummies for Maryland, Virginia and New Mexico.

Robust z-statistics in parentheses (clustered by state). ${ }^{*}$ indicates significance at $10 \%$ level,

${ }^{* *}$ at $5 \%$ and ${ }^{* * *}$ at $1 \%$. 
TAB 3: Effects of spending on voting decisions

\begin{tabular}{|c|c|c|c|c|}
\hline & $(1)$ & $(2)$ & (3) & $(4)$ \\
\hline $\begin{array}{l}\text { Dependent Variable: vote for the } \\
\text { incumbent in columns } 1-3 \text { and vote } \\
\text { Democratic in column } 4\end{array}$ & governor & president & senator & Congress \\
\hline
\end{tabular}

\begin{tabular}{|c|c|c|c|c|}
\hline$(1)$ & & & & \\
\hline federal expenditure & $\begin{array}{c}0.2851 \\
(0.92)\end{array}$ & $\begin{array}{l}-0.1295 \\
(1.80)^{*}\end{array}$ & $\begin{array}{l}-0.3230 \\
(1.20)\end{array}$ & $\begin{array}{c}-0.0507 \\
(0.97)\end{array}$ \\
\hline partisan match & $\begin{array}{l}2.2109 \\
(23.23)^{\star \star \star}\end{array}$ & $\begin{array}{l}2.0522 \\
(55.71)^{\star \star \star}\end{array}$ & $\begin{array}{c}1.9842 \\
(28.51)^{\star * *}\end{array}$ & \\
\hline ideology match & $\begin{array}{c}0.9000 \\
(15.41)^{\star \star *}\end{array}$ & $\begin{array}{c}0.7427 \\
(33.98)^{\star \star \star}\end{array}$ & $\begin{array}{c}0.6730 \\
(10.97)^{\star \star \star}\end{array}$ & \\
\hline $\begin{array}{l}\text { fed. exp. } x \text { democratic share of house } \\
\text { representatives }\end{array}$ & & & & $\begin{array}{c}-0.0033 \\
(0.05)\end{array}$ \\
\hline $\begin{array}{l}\text { share of Democratic } \\
\text { representatives in the House }\end{array}$ & & & & $\begin{array}{l}0.0803 \\
(0.33)\end{array}$ \\
\hline $\begin{array}{l}\text { Observations } \\
\text { Pseudo-R2 } \\
\end{array}$ & $\begin{array}{l}121570 \\
0.4523 \\
\end{array}$ & $\begin{array}{l}129429 \\
0.3646 \\
\end{array}$ & $\begin{array}{l}181350 \\
0.3559 \\
\end{array}$ & $\begin{array}{l}190944 \\
0.3407 \\
\end{array}$ \\
\hline ( 2 ) & & & & \\
\hline targetable spending & $\begin{array}{l}1.2421 \\
(1.80)^{\star}\end{array}$ & $\begin{array}{l}-0.1393 \\
(1.92)^{\star}\end{array}$ & $\begin{array}{l}-0.3303 \\
(1.08)\end{array}$ & $\begin{array}{c}0.0168 \\
(0.25)\end{array}$ \\
\hline partisan match & $\begin{array}{l}2.1195 \\
(22.73)^{\star \star *}\end{array}$ & $\begin{array}{l}2.2128 \\
(52.27)^{\star \star \star}\end{array}$ & $\begin{array}{c}1.9677 \\
(28.11)^{\star \star \star}\end{array}$ & \\
\hline ideology match & $\begin{array}{c}0.8779 \\
(14.24)^{\star \star *}\end{array}$ & $\begin{array}{c}0.7303 \\
(36.78)^{\star \star \star}\end{array}$ & $\begin{array}{c}0.6671 \\
(10.89)^{\star \star *}\end{array}$ & \\
\hline $\begin{array}{l}\text { targetable spend. } x \text { democratic share } \\
\text { of house representatives }\end{array}$ & & & & $\begin{array}{c}-0.0251 \\
(0.30)\end{array}$ \\
\hline $\begin{array}{l}\text { share of Democratic } \\
\text { representatives in the House }\end{array}$ & & & & $\begin{array}{c}0.1372 \\
(0.49)\end{array}$ \\
\hline $\begin{array}{l}\text { Observations } \\
\text { Pseudo-R2 } \\
\end{array}$ & $\begin{array}{l}109711 \\
0.4648 \\
\end{array}$ & $\begin{array}{l}141451 \\
0.3657 \\
\end{array}$ & $\begin{array}{l}175323 \\
0.3514 \\
\end{array}$ & $\begin{array}{l}174387 \\
0.3283 \\
\end{array}$ \\
\hline ( 3 ) & & & & \\
\hline grants & $\begin{array}{c}0.1538 \\
(0.09)\end{array}$ & $\begin{array}{c}0.3718 \\
(0.59)\end{array}$ & $\begin{array}{c}0.9469 \\
(0.89)\end{array}$ & $\begin{array}{l}0.5154 \\
(2.08)^{\star \star}\end{array}$ \\
\hline partisan match & $\begin{array}{c}2.2035 \\
(22.85)^{\star \star \star}\end{array}$ & $\begin{array}{l}2.0505 \\
(55.81)^{\star \star \star}\end{array}$ & $\begin{array}{c}1.9885 \\
(28.46)^{\star \star \star}\end{array}$ & \\
\hline ideology match & $\begin{array}{l}0.8998 \\
(14.75)^{\star \star \star}\end{array}$ & $\begin{array}{c}0.7309 \\
(36.53)^{\star \star \star}\end{array}$ & $\begin{array}{c}0.6737 \\
(10.91)^{\star \star \star}\end{array}$ & \\
\hline $\begin{array}{l}\text { grants } x \text { democratic share } \\
\text { of house representatives }\end{array}$ & & & & $\begin{array}{l}0.1688 \\
(0.78)\end{array}$ \\
\hline $\begin{array}{l}\text { share of Democratic } \\
\text { representatives in the House }\end{array}$ & & & & $\begin{array}{c}-0.0123 \\
(0.09)\end{array}$ \\
\hline $\begin{array}{l}\text { Observations } \\
\text { Pseudo-R2 }\end{array}$ & $\begin{array}{l}121570 \\
0.4518 \\
\end{array}$ & $\begin{array}{l}141451 \\
0.3646 \\
\end{array}$ & $\begin{array}{r}181350 \\
0.3555 \\
\end{array}$ & $\begin{array}{r}190944 \\
0.3408 \\
\end{array}$ \\
\hline
\end{tabular}

All regressions include a constant, year dummies, state fixed effects and the following control variables: income per capita, percentage of the population in schooling age, percentage of the population above the age of 65 , total population. The House regressions also include dummies for Democratic partisanship, Republican partisanship, liberal ideology and conservative ideology. Partisan match is a dummy equal to 1 if the voter has the same partisanship of the incumbent politician. Ideology match is a dummy equal to 1 if the voter is liberal and the incumbent politician is a Democrat, or if the voter is conservative and the incumbent is Republican. Robust z-statistics in parentheses (clustered by state). ${ }^{*}$ sign. at $10 \%$; ${ }^{* *}$ sign. at $5 \%$; ${ }^{* \star *}$ sign. at $1 \%$. 